\title{
Demographic Mechanisms of Reef Coral Species Winnowing from Communities under Increased Environmental Stress
}

\section{OPEN ACCESS}

Edited by:

Verena Schoepf,

University of Western Australia,

Australia

Reviewed by:

Erik Caroselli,

Università di Bologna, Italy

Aldo Cróquer,

Simón Bolívar University, Venezuela Hajime Kayanne,

The University of Tokyo, Japan

*Correspondence: Bernhard Riegl rieglb@nova.edu

Specialty section: This article was submitted to

Coral Reef Research,

a section of the journal Frontiers in Marine Science

Received: 28 July 2017 Accepted: 12 October 2017 Published: 27 October 2017

Citation:

Riegl B, Cavalcante G, Bauman AG,

Feary DA, Steiner $S$ and Purkis $S$ (2017) Demographic Mechanisms of Reef Coral Species Winnowing from

Communities under Increased Environmental Stress. Front. Mar. Sci. 4:344. doi: 10.3389/fmars.2017.00344

\author{
Bernhard Riegl $^{1 *}$, Georgenes Cavalcante ${ }^{2}$, Andrew G. Bauman ${ }^{3}$, David A. Feary ${ }^{4}$, \\ Sascha Steiner ${ }^{5}$ and Sam Purkis ${ }^{6}$
}

${ }^{1}$ Department Marine and Environmental Sciences, Halmos College of Natural Sciences and Oceanography, Nova Southeastern University, Dania Beach, FL, United States, ${ }^{2}$ Instituto de Ciências Atmosféricas, Universidade Federal de Alagoas, Maceió, Brazil, ${ }^{3}$ Experimental Marine Ecology Laboratory, Department of Biological Sciences, National University of Singapore, Singapore, Singapore, ${ }^{4}$ School of Life Sciences, University of Nottingham, Nottingham, United Kingdom, ${ }^{5}$ Institute for Tropical Marine Ecology, Roseau, Dominica, ${ }^{6}$ Comparative Sedimentology Laboratory (CSL), Department of Marine Geosciences, Rosenstiel School of Marine and Atmospheric Science, University of Miami, Miami, FL, United States

Winnowing of poorly-adapted species from local communities causes shifts/declines in species richness, making ecosystems increasingly ecologically depauperate. Low diversity can be associated with marginality of environments, which is increasing as climate change impacts ecosystems globally. This paper demonstrates the demographic mechanisms (size-specific mortality, growth, fertility; and metapopulation connectivity) associated with population-level changes due to thermal stress extremes for five zooxanthellate reef-coral species. Effects vary among species, leading to predictable changes in population size and, consequently, community structure. The Persian/Arabian Gulf (PAG) is an ecologically marginal reef environment with a subset of Indo-Pacific species, plus endemics. Local heating correlates with changes in coral population dynamics and community structure. Recent population dynamics of PAG corals were quantified in two phases (medium disturbed MD 1998-2010 and 2013-2017, severely disturbed SD 1996/8, 2010/11/12) with two stable states of declining coral frequency and cover. The strongest changes in life-dynamics, as expressed by transition matrices solved for MD and SD periods were in Acropora downingi and Porites harrisoni, which showed significant partial and whole-colony mortality (termed "shrinkers"). But in Dipsastrea pallida, Platygyra daedalea, Cyphastraea microphthalma the changes to life dynamics were more subtle, with only partial tissue mortality (termed "persisters"). Metapopulation models suggested recovery predominantly in species experiencing partial rather than whole-colony mortality. Increased frequency of disturbance caused progressive reduction in coral size, cover, and population fecundity. Also, the greater the frequency of disturbance, the more larval connectivity is required to maintain the metapopulation. An oceanographic model revealed important local larval retention and connectivity primarily between adjacent populations, suggesting that correlated disturbances across populations will lead to winnowing of species due to colony, tissue, and fertility losses, with resultant insufficient dispersal potential to make up for losses-especially if disturbances increase under climate change. Variable extinction 
thresholds exist based on the susceptibility of species to disturbance ("shrinkers" vs. "persisters"), determining which species will be winnowed from the community. Besides projected changes in coral community and population structure, no species are projected to increase in cover. Increased marginality due to climate change will lead to a net loss of coral cover and novel communities in PAG.

Keywords: coral reefs, climate change, Persian/Arabian gulf, population dynamics, matrix model, oceanographic model, metapopulation, connectivity

\section{INTRODUCTION}

Gradients in latitude, habitat, and anthropogenic disturbance characterize the distribution of biodiversity in general, and also of zooxanthellate reef-building shallow-water corals (Reaka et al., 2001; Schluter and Pennell, 2017). Reef-coral diversity declines from a presumed center toward the edges (Rosen, 1971; Coudray and Montaggioni, 1982; Jokiel and Martinelli, 1992; Veron, 1995; Glynn, 1997; Veron et al., 2009). This pattern is usually ascribed to physiological limitations of zooxanthellate reef corals in marginal environments of the tropical belt. Increased excursions from a typical tropical environmental envelope seems to determine the limits of adaptation (Veron, 1995; but see discussion concerning the Mid Domain Effect; Colwell et al., 2004; Connolly, 2005; Hawkins et al., 2005; Currie and Kerr, 2008). These mechanisms are not only evident along latitudinal gradients but increasingly also along temporal and anthropogenic gradients (vanHooidonk et al., 2013; Riegl and Purkis, 2015; Hughes et al., 2017a,b; Schluter and Pennell, 2017). Although species may evolve and adapt to new conditions (Jones et al., 2008; Atweberhan et al., 2013; Makino et al., 2014; Palumbi et al., 2014), generally fewer reef-coral species persist within suboptimal environments. Peripheral endemism can counter-act at least some diversity-loss, with some peripheral seas speciespoorer than the distributional center but rich in local endemics, and some marginal environments of the tropical belt appear to be centers of evolutionary innovation (Jokiel and Martinelli, 1992; Reaka et al., 2001; Budd and Pandolfi, 2010). Even within highest-diversity zones, gradients in environmental quality cause gradients of species richness, with species winnowed from zones beyond their physiological or ecological optima (Veron, 1995).

Climate change increases variability of diversity-controlling parameters. Temperature and photosynthetically active irradiation are key determinants of coral distribution and many future climate projections suggest physiologically unsustainable changes (Sheppard, 2003; Donner et al., 2005; vanHooidonk et al., 2013; Cacciapaglia and vanWoesik, 2015). This may alter geographic distributions of many coral species through increased frequency and severity of mortality (Jackson, 2001; Sheppard, 2003; Donner et al., 2005; Cacciapaglia and vanWoesik, 2015; Hughes et al., 2017a,b), retarded regeneration (Osborne et al., 2017), or range extension (Precht and Aronson, 2004; Yamano et al., 2011). Dramatic changes in community patterns have already been observed (Harii et al., 2014; Hughes et al., 2017a). In the Caribbean, marginal reef areas like Florida suffered severe reduction of their most important frame builders Acropora and Orbicella (Jaap et al., 2008). The Persian/Arabian
Gulf (PAG) is another marginal sea where coral cover has precipitously declined concomitant with increased disturbances (Riegl, 1999; Purkis and Riegl, 2005; Burt et al., 2011; Bauman et al., 2013; Riegl and Purkis, 2015; Bento et al., 2016) that changed population and community dynamics (Riegl and Purkis, 2015). Due to its shallow nature (maximum depth $90 \mathrm{~m}$ ) and high-latitude position $\left(24-30^{\circ} \mathrm{N}\right)$ within an area of rapid temperature increase (Hoegh-Guldberg et al., 2014), PAG is well-suited to explore effects of climate change and other human impacts on the demographics, and thus future persistence, of corals (Sheppard et al., 2010; Burt et al., 2011; Purkis et al., 2011; Riegl and Purkis, 2012; Bauman et al., 2013).

Coral community dynamics related to disturbance has changed in southeastern PAG. Pre-1996, disturbances due to unusual heat or cold recurred $\sim 15-20$ years (Riegl, 1999; Riegl and Purkis, 2009, 2012) with coral mortality $\sim 50$ but $>90 \%$ of all Acropora dying. This disturbance frequency and severity was apparently typical for most of the Holocene until the closelyspaced events of 1996 and 1998 (Riegl and Purkis, 2009, 2012). From 1998-2010 and from 2012-2017, moderate disturbances recurred every 5 years, again preferentially killing Acropora, with $\sim 10 \%$ overall coral mortality. Closely-spaced disturbances, such as, in 1996/8, 2010/11/12, caused annual or biennial severe mortality with no intermittent regeneration possible due to short spacing of successive events. Coral mortality of $\sim 20-50 \%$ and Acropora mortality of $\sim 90 \%$ were typical (Riegl, 1999; Burt et al., 2008, 2011; Riegl and Purkis, 2012, 2015).

These phases of disturbance-spacing are reflected in coral communities, due to species-specific differences in mortality. Coral cover declined across PAG since 1996/1998 (Figures 1A,B) and a progression in dominance from Acropora to Porites to merulinids (where summed merulinid cover exceeded that of Porites, Figure 1C) with increased disturbance-frequency has been recorded (Riegl and Purkis, 2015).

The disturbance-mediated change in community composition along the time-axis (Riegl and Purkis, 2015) resembles the partitioning of coral communities along a geographical gradient of increasing environmental stress across southern PAG (Sheppard, 1988). With more heat and salinity, branching genera (Stylophora and Acropora) are generally replaced by columnar massives (Porites harrisoni) and, in the more extreme habitats primarily merulinids. Since climate warming may cause an expansion of high salinity and high temperature regimes in PAG, more habitat may become marginal and therefore become characterized by higher cover of stress-adapted corals. In turn, less-tolerant species from the assemblages may eventually disappear from the entire region. 

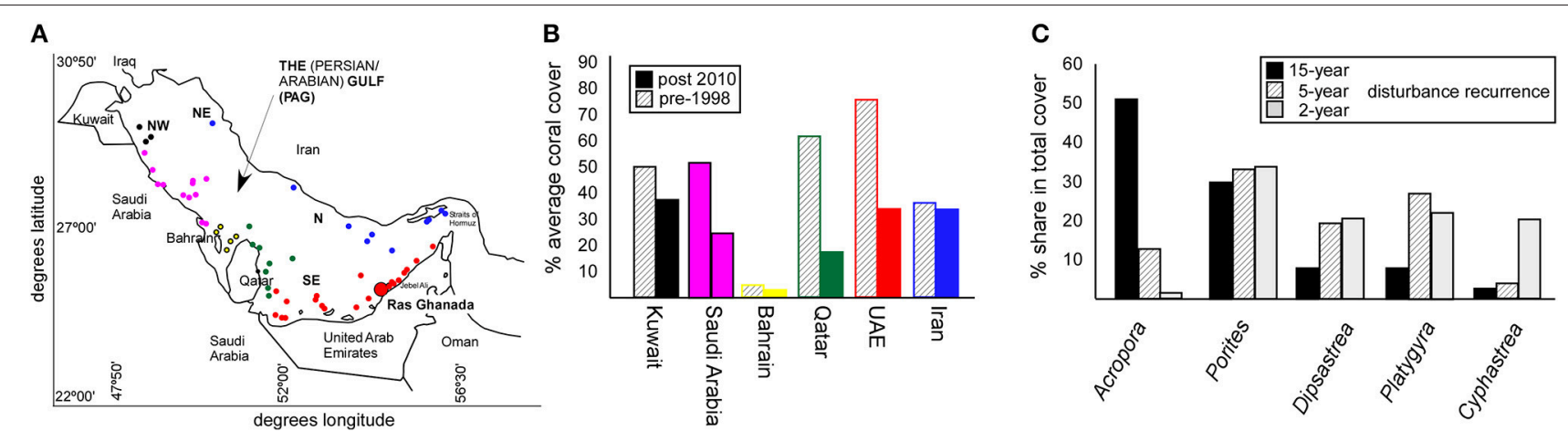

FIGURE 1 | Effects of temperature-related disturbances (bleaching events) on coral cover and coral community structure across PAG. (A) Map of the Persian/Arabian Gulf (PAG). Colored dots show reef locations that were used to derive coral cover trends shown in (B) Coral cover changes from the period with the least known disturbances preceding the 1996/8 first double-bleaching event, to after the severe 2010/11/12 disturbances. Color of bars corresponds to color code of reef locations in panel A. (C) Each disturbance phase (15-year disturbance spacing; 1-2 year disturbance spacing, 5-year disturbance spacing) is reflected in community structure at a monitoring site at Ras Ghanada, Abu Dhabi.

While patterns of species attenuation with increased environmental stress have been described (Kayanne et al., 2002; Harii et al., 2014), more details of associated processes, physiological and especially demographic, are needed (Pratchett et al., 2017). To examine the amount of plasticity among species, and the local or global loss of species that cannot persist in changing environments, it is important to understand which coral life-history stage may be most susceptible to changes in survival probability. The present study explores changes in demographics of the most common reef corals in PAG (Sheppard and Sheppard, 1993; Riegl, 1999) over the last decade. The five most common reef-coral species in southeastern PAG (Acropora downingi, P. harrisoni, Dipsastrea pallida, Platygyra lamellina, Cyphastrea microphthalma) were selected for a 10-year monitoring time-series, in which size-class specific survival, growth, shrinkage due to partial tissue loss, as well as estimated fertility and connectivity were quantified. With thus parameterized transition matrices, population trajectories were forecast. The connectivity across the region was quantified with an oceanographic model that allowed tracking of theoretical coral larvae release from the region. Subsequently a metapopulation matrix model was developed to evaluate changes in connectivity and meta-population persistence caused by changes in demographic parameters of the corals caused by environmental (here: temperature) stress. Overall, the study seeks to demonstrate whether temperature-driven modifications in survival and growth probabilities of individual species (Riegl and Purkis, 2015) will be sufficient to cause shifts in population structure (colony size distribution), resulting in altered fertility, connectivity, and changed species composition in communities.

\section{METHODS}

\section{Environmental Conditions and Coral Condition}

To understand the distribution of coral communities under different PAG environmental regimes, coral assemblages were assessed by photo-transects at various reefs in Qatar (Fasht el Hurabi, Khor al Odaid, Ras Rakan, Halul) and the United Arab Emirates (UAE) (Ras Ghanada, Makasseb, Yasat Islands, Delma, Arzanah, Das). These data, along with data from published literature (Purser, 1973; Sheppard, 1988; Fatemi and Shokri, 2001; Rezai et al., 2004, 2010; Purkis and Riegl, 2005; Aramco, 2007; Burt et al., 2011, 2013; Kavousi et al., 2011; Foster et al., 2012; Riegl and Purkis, 2012; Bauman et al., 2013, 2014; Mohammadizadeh et al., 2013; Grizzle et al., 2016; Shuail et al., 2016), were used to produce Figure 1.

Temperature is among the most obvious drivers in latitudinal patterns of zooxanthellate reef-coral species (Veron, 1995) and a key driver of coral bleaching, which causes variable coral mortality among species (Loya et al., 2001; vanWoesik et al., 2011). Water temperatures were continuously recorded from 2014 to 2017 at Ras Ghanada at $6 \mathrm{~m}$ water depth (hightide) in Abu Dhabi, UAE using in-situ loggers (VEMCO Minilog II and HOBO Temp II). A longer-term air-temperature dataset of daily means, maxima and minima from Sharjah airport (since 1944, continuous data since 1978), situated $98 \mathrm{~km}$ away from the coral monitoring site was also obtained (klimexp.kmnl.nl). For the 4 years of continuous data recording on the reef, daily means, maxima and minima were regressed against the Sharjah air-temperature dataset. Since the coral monitoring site was shallow and Gulf water temperatures are notoriously responsive to air temperatures (review in Riegl and Purkis, 2012; Riegl et al., 2015), close coincidence was expected. Analyses of relationships between temperature and mortality concentrated on mean conditions, rather than extremes in the dataset, since in-situ water-temperature recordings only recorded a recovery period and the last disturbance. While means (monthly, seasonally, annually) of air and water temperature can be expected to be robustly correlated, this is not necessarily the case with extremes and variance. Since several hours are required for even a shallow marine water body to equilibrate with air temperatures, we decided that inclusion 


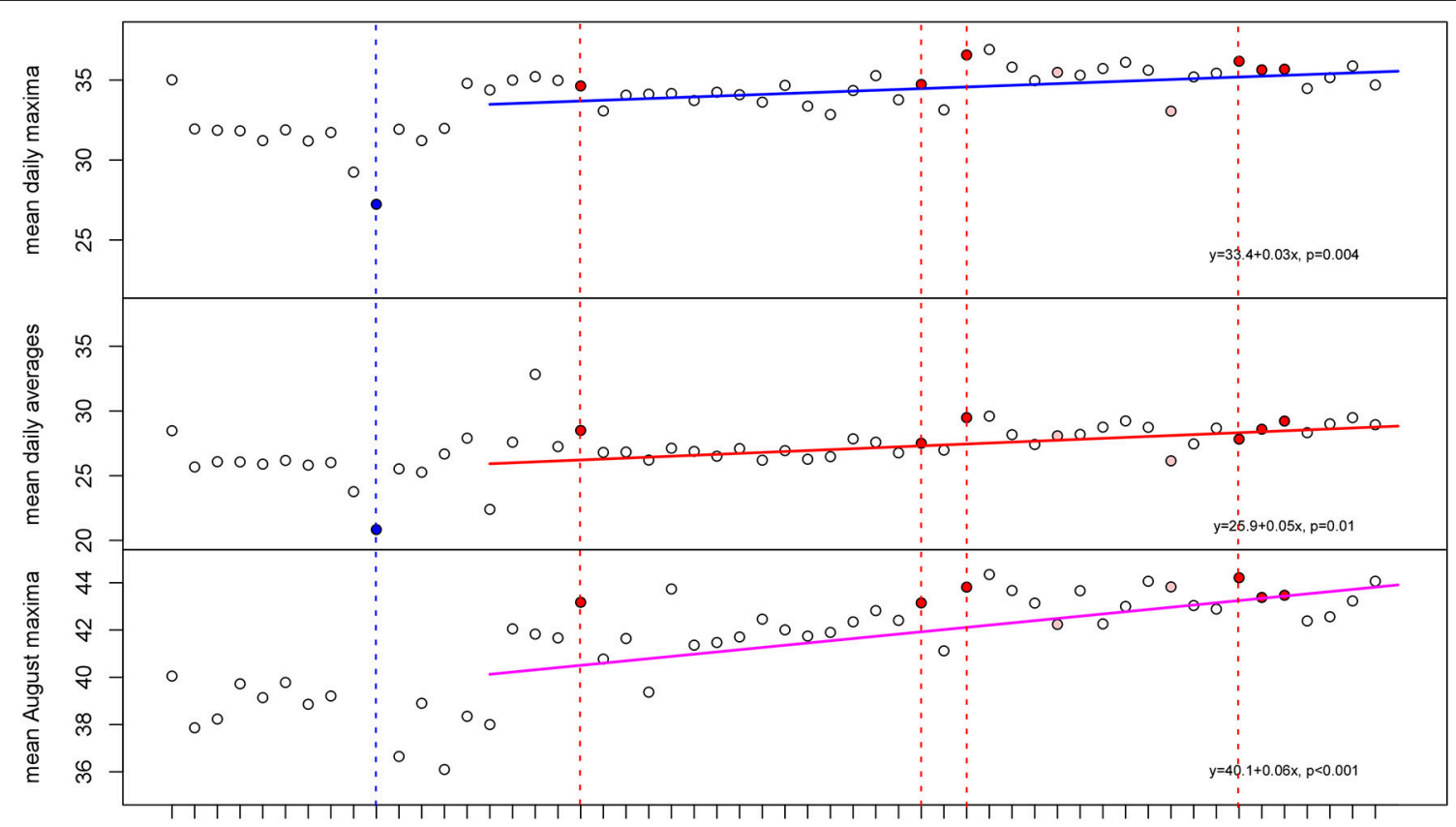

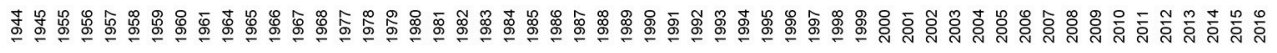

FIGURE 2 | Air temperatures at Sharjah airport, $97 \mathrm{~km}$ from the monitoring site (correlation of air temperatures and water temperatures at the monitoring site $R^{2}=$ 0.88). It is clearly visible that over the measured period (complete data since 1977, therefore regressions begin in 1977) temperature stress indicators, especially mean daily maxima in August, the bleaching month, have steadily increased. Known local bleaching and mass coral mortality events shown by vertical red broken line and red dot if unusual heat was implicated, blue if unusual cold was implicated (only 1964) in coral mortality events. The high temperatures in 1985 and 1999 were not identified as significant bleaching events primarily because they had been preceded by mass coral mortality that had left few corals to be impacted.

of extremes and variance of air temperature as proxy for the corals' environment might have introduced spurious results (Figure 2).

The preferential distribution of PAG corals with regards to environmental conditions such as preferred depth, salinity, and average temperature ranges was determined from our own samples and information in the literature (Sheppard, 1988; Sheppard and Sheppard, 1993; Riegl, 1999; Riegl and Purkis, 2012). The naturally occurring gradients in these conditions roughly follow from most benign conditions on offshore reefs, to more stressful conditions on inshore reefs, to the most stressful conditions in embayments and lagoons such as, in the Gulf of Salwah or the Abu Dhabi lagoons (Purser, 1973; Sheppard and Sheppard, 1993) and are generalized in Figure 3.

\section{Matrix-Based Derivation of Coral Population Dynamics}

Coral population dynamics were monitored continuously at the same reef sites in southern PAG at Ras Ghanada (Abu Dhabi, UAE) over the last 10 years. Data exist from 1996 onward, but between 2007 and 2017, at two sites, 40 phototransects consisting of overlapping $0.75 \times 5 \mathrm{~m}$ photos, were placed haphazardly within $50 \mathrm{~m}$ of GPS-defined points three times per year. Merged images were re-gridded to unit pixel-size (1 pixel $=1 \mathrm{~mm}^{2}$ ), corals were identified, outlines were digitized and assigned a unique color. For the purpose of colony counts, any freestanding coral colonies or parts thereof with living tissue were considered individuals (Bauman et al., 2013), a definition allowing to include partial tissue mortality as mechanism of fission and asexual reproduction. Coral areas were measured as horizontally projected surface area within five size bins defined by radius: size class 1 (=SC1, recruits and very young corals), SC2 (young corals), SC3 (corals entering sexual maturity above a given puberty size, however, variability can exist in minimum size at puberty; Soong, 1993), SC4 (large corals), and SC5 (very large corals $=$ relatively rare). Size-classes are justified by lifehistory traits from literature (citations in Riegl et al., 2012b). The five most common species (A. downingi, P. harrisoni, D. pallida, P. lamellina, C. microphthalma) with the highest proportional cover in the community were chosen for detailed investigation. Diameters defining SCs differed among species (A. downingi: $<10,10.1-50,50.1-90,90.1-120,>120 \mathrm{~m}$; P. harrisoni: $<5,5.1-$ 25, 25.1-45, 45.1-65, >65 cm; D. pallida: <2, 2.1-6, 6.1-10, 10.1-14, >14 m; P. lamellina: <3, 3.1-6, 6.1-12, 12.1-24, >24 m; C. microphthalma: $<3,3.1-6,6.1-12,12.1-24,>24 \mathrm{~cm})$. To avoid excluding the largest corals, those that were truncated at edges of the transect image were included if their diameter or projected area within transects were sufficient to placed them in SC3 or SC4. SC5 corals were rare and were counted by $30 \mathrm{~min}$ roving diver surveys. Small truncated corals (i.e., that only partially fell within the phototransect) were ignored since inclusion might have artificially bolstered smaller size-classes than the truncated corals actually belonged to. Since numbers of recruits varied and showed a clumped distribution (see also 


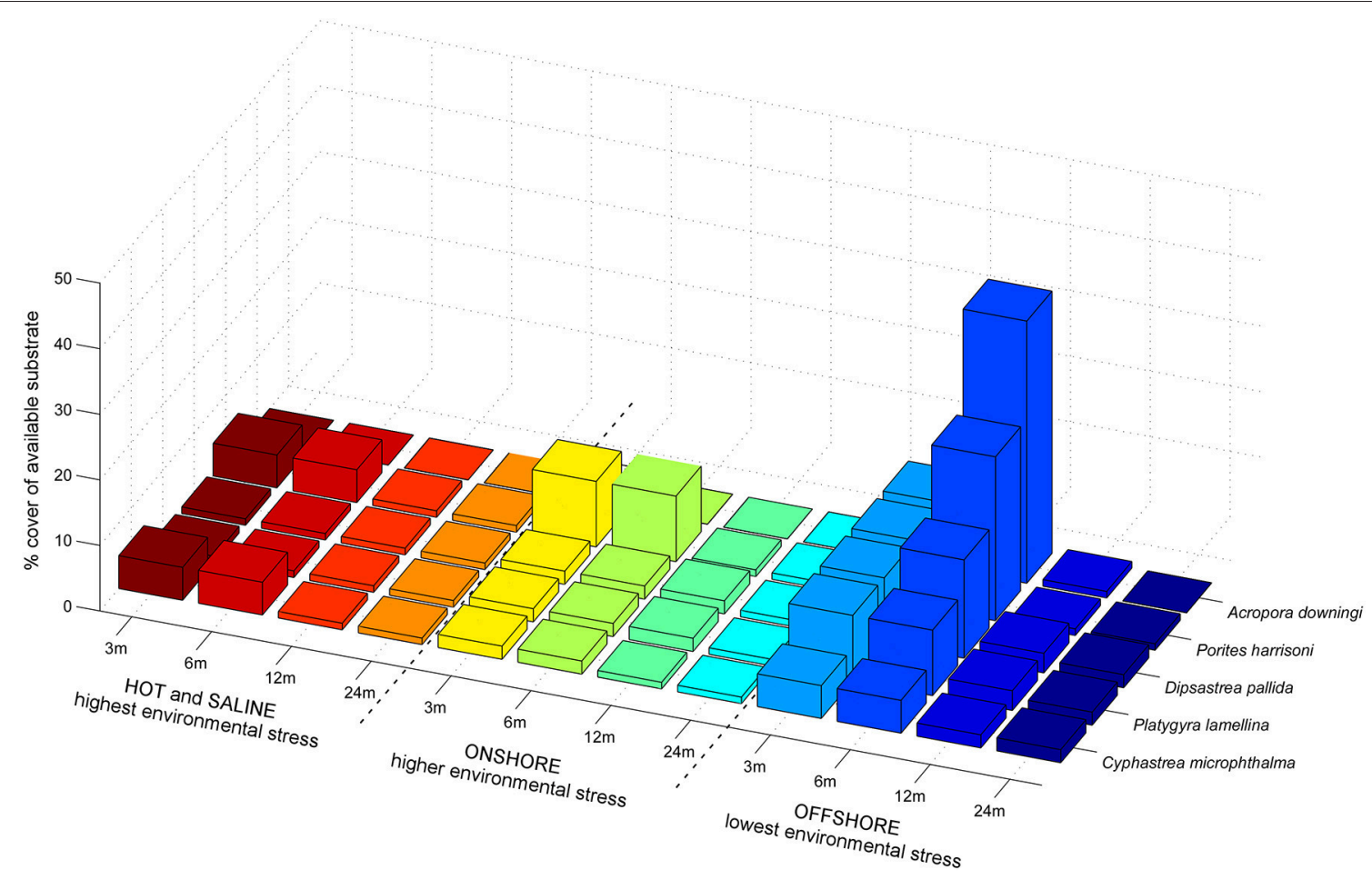

FIGURE 3 | Preferential habitat distribution of the evaluated species in PAG. The gradient of environmental quality from coral-friendly to harsh, goes from right to left. Temperatures are lowest and most equitable on offshore reefs (Riegl and Purkis, 2012). Marked changes are observed in the occurrence and dominance of species, which suggests that similar changes may be expected if environments change over time. "Offshore" environments are typical of the numerous offshore islands in the Gulf and coral communities situated several km from the mainland shoreline in well-flushed areas (such as, the monitoring site at Ras Ghanada). "Onshore" environments are found near the mainland shore, for example in tidal passes in Abu Dhabi or Qatar, "Hot and saline" environments are found for example within the lagoons behind the Abu Dhabi barrier islands, entrances to Qatar's Khor al Odaid or the Gulf of Salwah.

Bauman et al., 2011, 2014) and recruits were often found close to larger corals, potential confusion existed with asexual propagules. Due to the difficulty of obtaining consistent and defensible counts of sexual recruits, this size-class was included in a larger SC1 (of, depending on species, $2-10 \mathrm{~cm}$ diameter), which also included many asexual recruits (i.e., coral fragments).

Two distinct periods existed with regards to disturbances during the 10-year monitoring period. A sequence of strong disturbances occurred in 2010/11/12 with coral bleaching and disease outbreaks. This period was a discrete pulse of heat-related stress that had clearly visible effects on coral populations. Thus, a transition matrix (the severe disturbance $=$ SD model) was created for this period. The period from 2007-2010 and from 2013-2017 was characterized by the absence of severe stress with only moderate bleaching in 2007, but no mortality. Thus, a transition matrix (the moderate disturbance $=\mathrm{MD}$ model) was created for this period. This was done using Wood's method (Caswell, 2001), essentially a linear optimization approach, on the sequence of size-class distributions in population vectors that contained primarily survival, growth, and shrinkage probabilities. These size-class transition models were verified by back-testing in model runs that began by multiplying the transition matrices by the first (oldest) monitoring population vector that had not been used when solving for the matrix, running for as many time-steps as available from the monitoring effort (max. $N=19$ ), and comparing results (Riegl and Purkis, 2015; Zhao et al., 2016). Several possible transition models could be solved, as defined by constraint matrices that define matrix positions into which values are optimized. The one with lowest RMS (root-mean-squared) error of hindcast vs. the observed vectors was chosen. Matrices are shown in this paper as lifecycle graphs with bubble-sizes in each SC scaled to proportional contribution to the right eigenvector corresponding to the dominant eigenvalue (Figure 4). In matrix models, a theoretical stable size-class distribution is expressed by the right eigenvector and the corresponding eigenvalue is akin to a population's asymptotic growth rate (if $>1$ the population will grow; Caswell, 2001). Note must be taken that stable size-class distribution can best be reached in a closed population (recruits are exclusively derived from within the modeled population) and only then is the dominant eigenvalue an adequate approximation of population growth rate.

The matrices solved from the undisturbed period could be compared to those of the disturbed period as a Life Table Response Experiment (LTRE; Caswell, 2001) which allowed exploration of the influences of changes in life-stages (i.e., survival/growth/shrinkage probabilities of individual SCs) on the eigenvalues (Figure 5). 


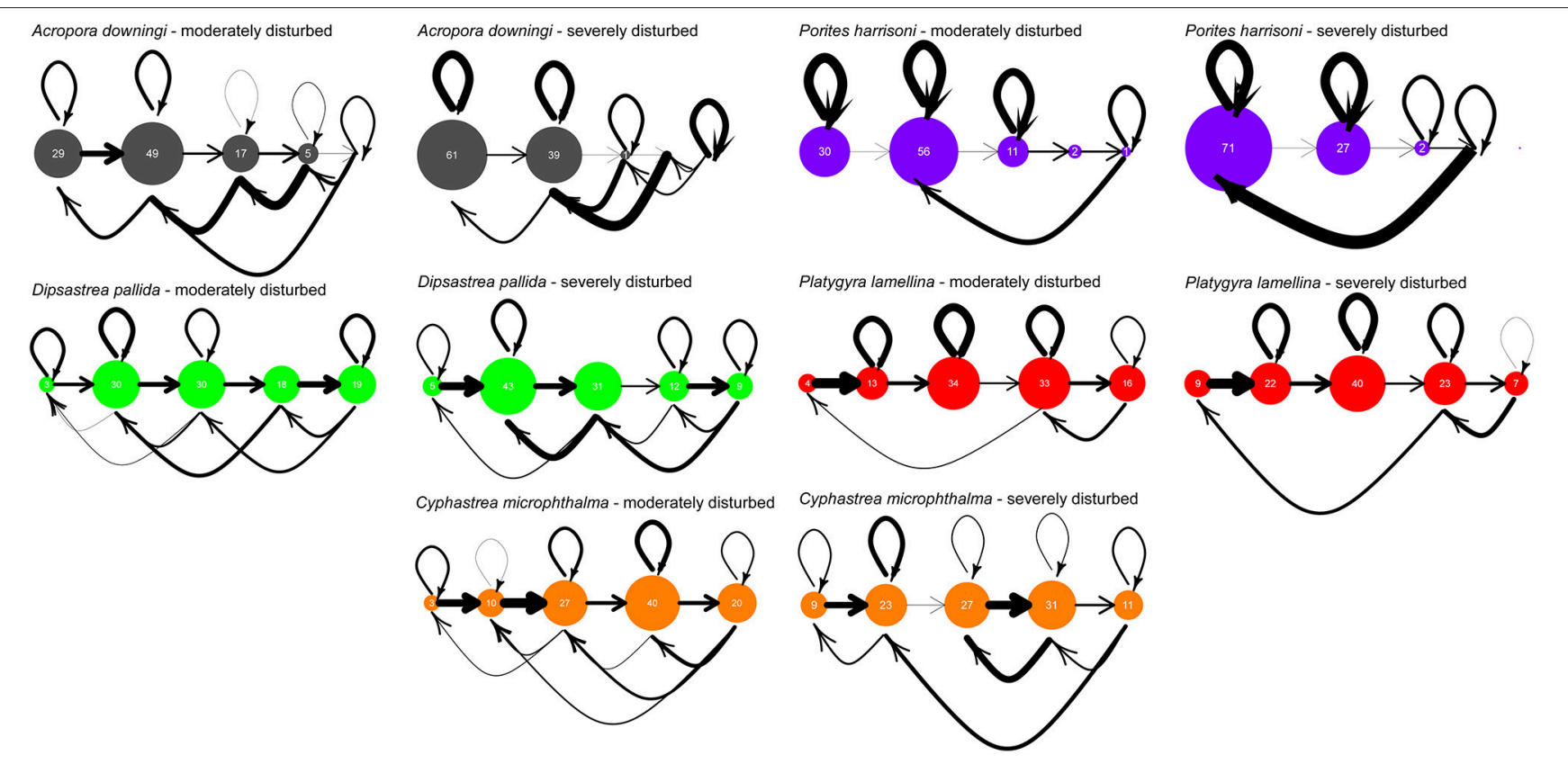

FIGURE 4 | Life-cycle graphs of the evaluated species, based on 10 years of monitoring at Ras Ghanada, Abu Dhabi. Bubble size is relative to proportional frequency of size class in the eigenvector corresponding to the dominant eigenvalue of the matrix, i.e., the theoretical expected size distribution. Closed populations will tend to converge onto this distribution and it is therefore of theoretical interest. The thickness of arrows is related to the value of transition likelihood-bold arrows are values close to 1 , the thinner the arrow, the closer to 0 (life-stage transitions range $0-1$, i.e., the proportion of individuals transiting between stages).

To estimate fertility (i.e., production of gametes), data from Bauman et al. (2011), Howells et al. (2016), both from PAG reefs, and Shlesinger et al. (1998) from the Red Sea, were used for estimation of number of oocytes per polyp or mesentery. The following values.cm ${ }^{-2}$ were assigned: 12 polyps $* 14$ oocytes. $\mathrm{cm}^{-2}$ in A. downingi, 60 polyps (30 female) $* 10$ oocytes. $\mathrm{cm}^{-2}$ in $P$. harrisoni (this species is gonochoric with unknown sex ratio in the examined population, thus a ratio of 1:1 was assumed), 1 polyp ${ }^{*} 700$ oocytes. $\mathrm{cm}^{-2}$ in $D$. pallida, 15 polyps $* 78$ oocytes. $\mathrm{cm}^{-2}$ in C. microphthalma, and 20 mesenteries * 14 oocytes. $\mathrm{cm}^{-2}$ in Platygyra daedalea. Fecundity calculated as number of polyps/mesentaries. $\mathrm{cm}^{-2} *$ number of oocytes per polyp/mesentery * projected surface area of colony, expressed as "standard fecundity," which was the summed oocyte output of 100 colonies apportioned into observed fertile size classes (SC3 through SC5). This process accounted for sizedependency of life-processes, especially fecundity (Hughes et al., 2000). A space cover of " 1 " was assigned to 100 colonies (see above). Disturbances reduce space cover and to obtain per-spatial-unit reproductive output, "per unit" fecundity was reduced by multiplication of "standard fecundity" by decline in space cover. A given fecundity value (for example, 1,000 oocytes in 100 corals with a cover-value 1) decreased with availability of fewer individuals and thus less reproductive surface-area (example: 1,000 oocytes in 100 corals $* 0.5 * 0.5$, if overall cover was halved and cover of the fertile SCs was also halved). See also Riegl and Purkis (2015). These values were used for Figure 6. All corals treated in this paper are broadcast spawners (Shlesinger et al., 1998; Kongjandtre et al., 2010; Bauman et al., 2011).

\section{Theoretical (Matrix-Based) Connectivity Considerations}

Metapopulation models allowed quantification of the effects of connectivity and disturbance (the parameters to which the model had highest sensitivity) into a single index called "connectivity requirement," which refers to the required recruit flow among sub-populations to maintain a growing trajectory of the meta-population. Models were created separately for all five species, and consisted of a combined matrix of several sub-matrices (variably $\mathrm{MD}, \mathrm{SD}$ ) with a connectivity component and added local recruitment (values $>1$ in SC4 and SC5) in the most upstream population (Figure 7). Using a variable combination of the known matrices (LD-matrix upstream, MDmatrix downstream) uncorrelated fates across metapopulation, and correlated fates across the metapopulation (exclusively MDor SD matrices up- and downstream) and climate change effects (reduced connectivity; Figueiredo et al., 2014), were examined.

The metapopulation matrix consisted of four connected subpopulations (transition matrices, inset Figure 7) with either one-way $(\mathrm{P} 1 \rightarrow \mathrm{P} 2 \rightarrow \mathrm{P} 3 \rightarrow \mathrm{P} 4)$ or two-way connectivity in populations 3 and $4(\mathrm{P} 1 \rightarrow \mathrm{P} 2 \rightarrow \mathrm{P} 3 \leftrightarrow \mathrm{P} 4)$. This metapopulation structure was suggested by the oceanographic connectivity model (see below). Step-wise, 10-fold decrease of local recruitment (added as a fractional multiplier) in subpopulation 1 and in connectivity between the remaining subpopulations, were examined. Outcome of the models was a quantification of "connectivity requirement," which is a multiplier of the reproducing SC4-5, determining how many successful recruits each individual of an upstream subpopulation must establish in 

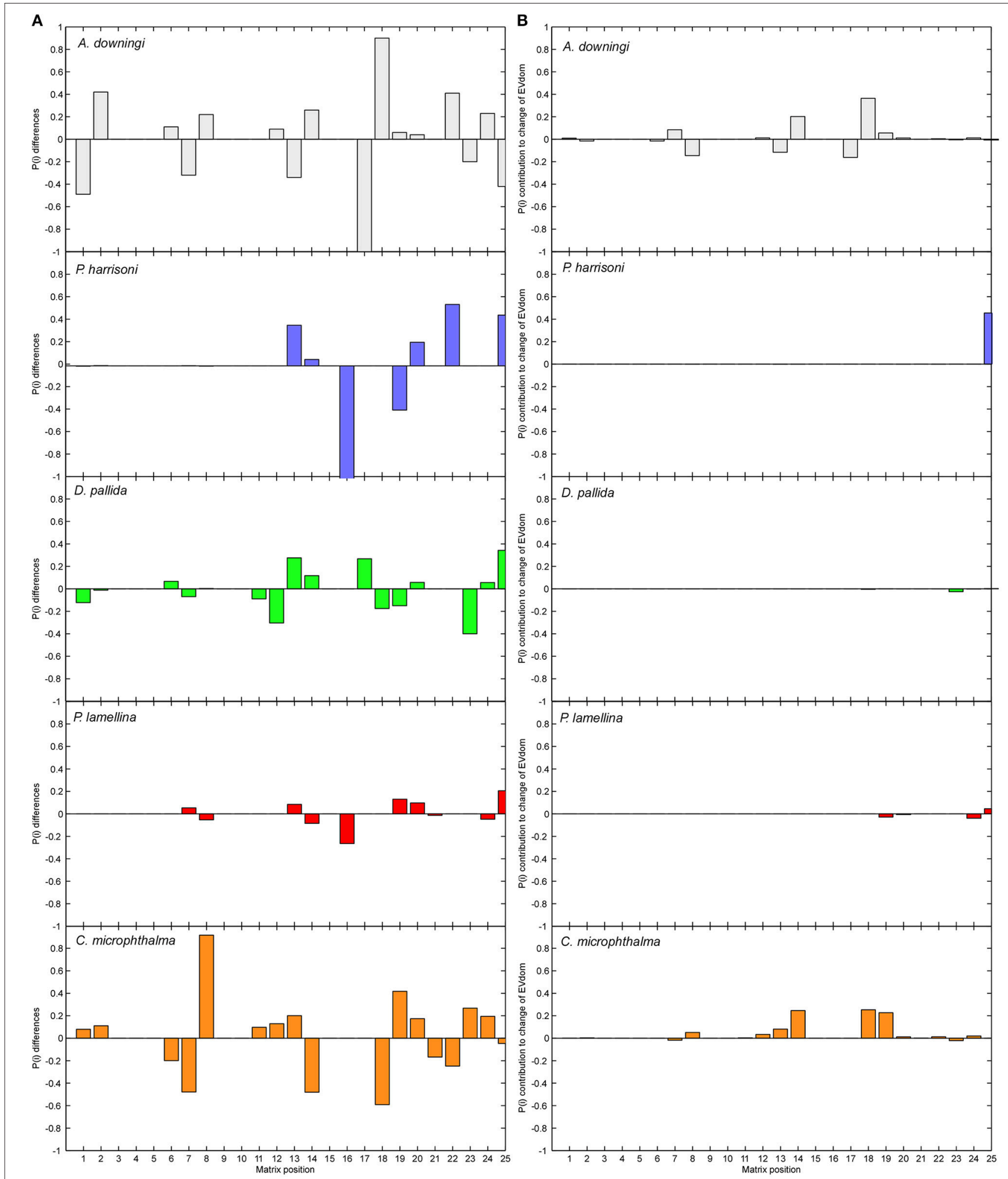

FIGURE 5 | Treatment of disturbances as LTRE (Life Table Response Experiment). Column (A) shows the difference in matrix positions between the MD and SD matrices Column (B) shows the influence of each of these changes on the dominant eigenvalue. Matrices were expressed in vector form (matrix column 1 is vector positions 1-5, matrix column 2 is vector positions 6-10, and so on until vector position 25). In (A) the contribution of vector position 16 (transition from SC4 into SC1, largely shrinkage into small tissue fragments) is truncated in $P$. harrisoni (true value -5 ). 

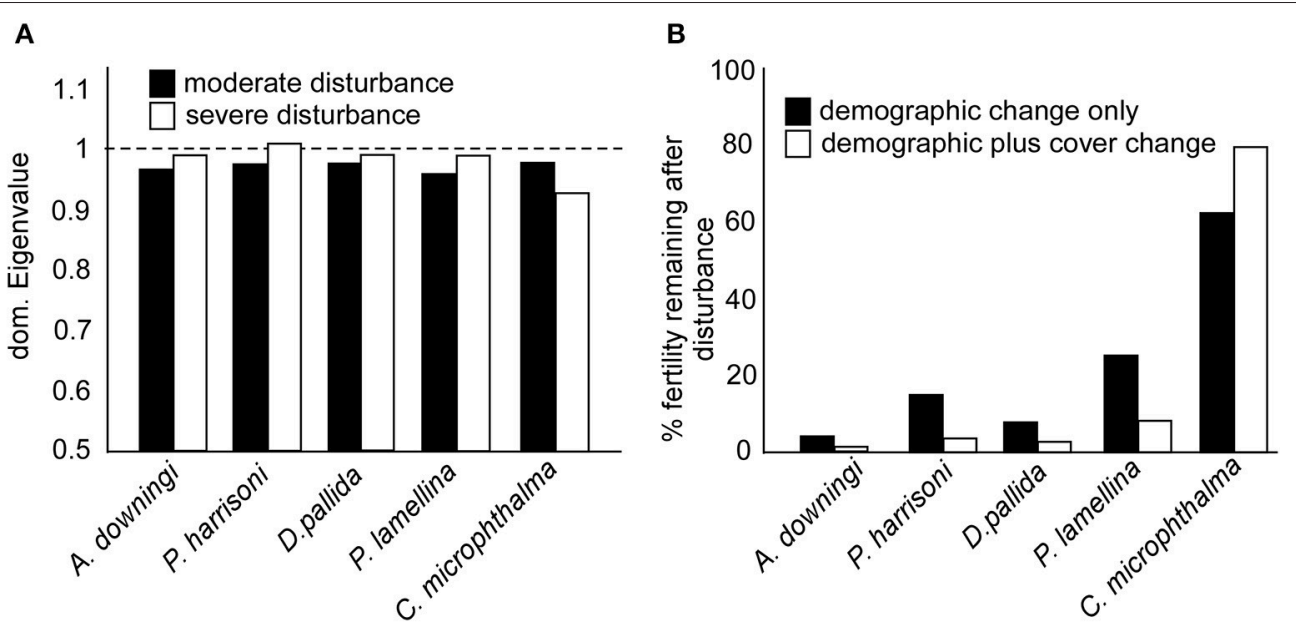

FIGURE 6 | (A) Asymptotic rates of population increase (dominant eigenvalues) of moderate disturbance (black bars) and severe disturbance (white bars) size-transition models. A value of 1 (broken line) is needed for population stability, smaller values indicate a shrinking population. (B) Changes in Standard fecundity (expressed as oocytes per 100 colonies) prior to, and after, the significant coral cover reduction of 2011-2013. Changed size distributions reduce fecundity (black bars), which is exacerbated by reduced overall coral cover (white bars). "standard fecundity" is relative to 100 fertile (SC3-5) colonies, standard fecundity was multiplied by the proportion of space-cover (planar coral area) remaining after the disturbances and the proportion of corals in SC3-5 (see section Materials and Methods).

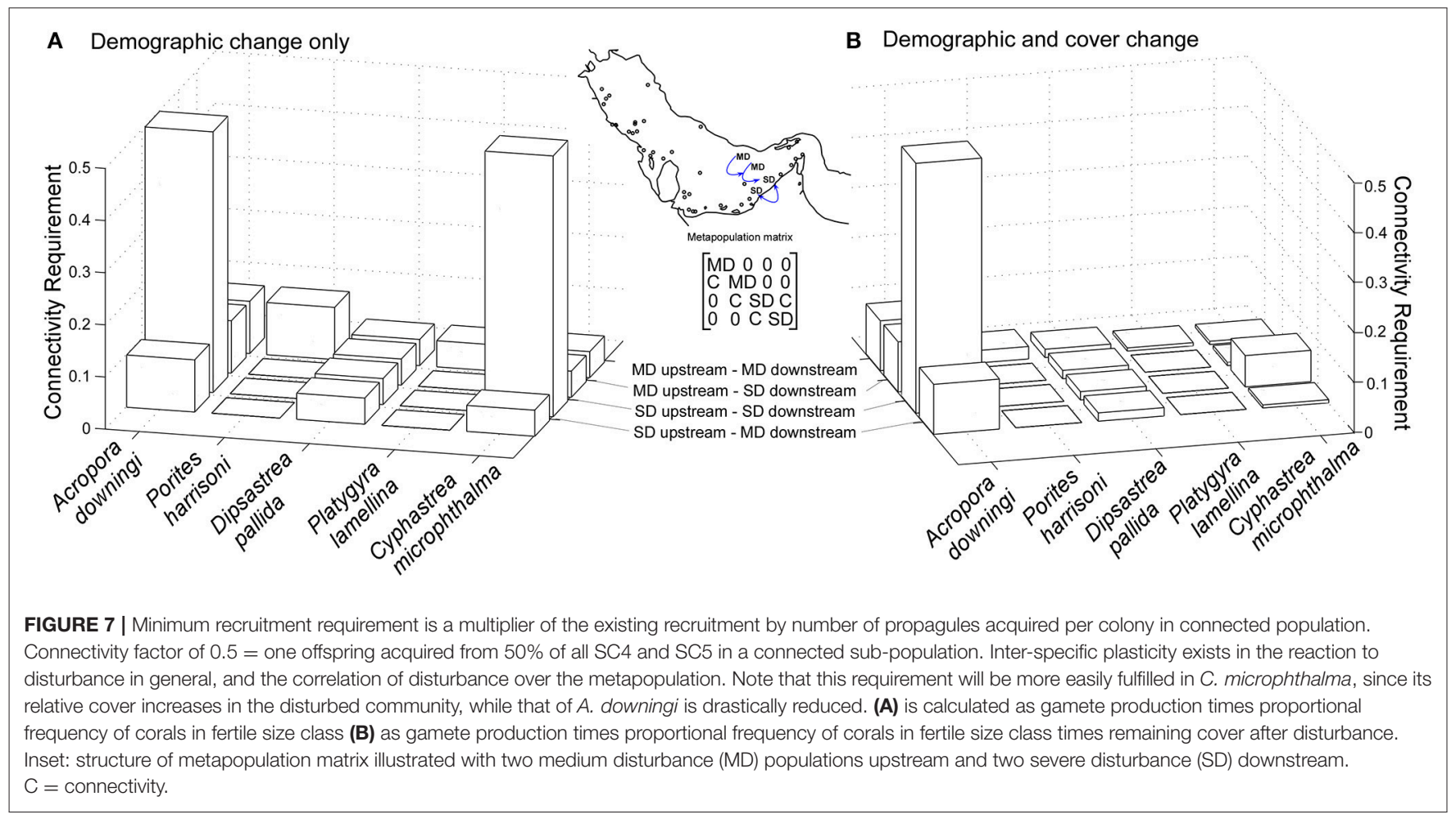

the downstream subpopulation for the entire metapopulation to maintain a positive asymptotic population growth rate $(=$ dominant eigenvalue of metapopulation matrix $>1$ ). The correlation of disturbance across the metapopulation could be controlled by whether only few, or all connected populations switched from MD to SD matrices (see four scenarios in Figure 7).

\section{Oceanographic Model of Connectivity}

To model larvae transport and to validate estimates of connectivity and recruitment, an oceanographic model for the area $47^{\circ} \mathrm{E}$ to $59^{\circ} \mathrm{E}$ longitude and $21^{\circ} \mathrm{N}$ to $31.5^{\circ} \mathrm{N}$ latitude was developed (Cavalcante et al., 2016). Bathymetry used a $2 \mathrm{~km}$ Cartesian grid offshore and $50 \mathrm{~m}$ in the nearshore region. Bathymetry data were from RDA (http://dss.ucar.edu) based at 
CISL Research Data Archive; datum value of MSL $+1 \mathrm{~m}$ was selected. MIKE 21, a two-dimensional depth-averaged Eulerian time integration scheme was then utilized to compute current velocities in the model domain (DHI Water and Environment, 2001; Cox, 2003; Kankara et al., 2007; Zhao et al., 2014). A time step of $60 \mathrm{~s}$ was selected during the calibration and validation period (March 2010). The forward model (27 April to 19 June 2010) was run based on the output produced from the velocity field during the warm up period (12-27 April 2010), meaning that the initial velocity field and initial boundary forcing were not initiated in "cold-start" mode. Zonal and meridional wind components, pressure, and tidal elevations along the offshore boundary at the $59^{\circ} \mathrm{E}$ longitude were introduced. Model runs used following coefficients: wind friction factor (0.001255), Manning's number $\left(38 \mathrm{~m}^{1 / 3} \mathrm{~s}^{-1}\right)$ and Eddy viscosity coefficient (Smagorinsky formulation) (0.28). Wind components were 1$\mathrm{h}$ averages of effective neutral wind at a height of $10 \mathrm{~m}$ and within grid spacing of $0.25^{\circ}$ in both zonal and meridional wind directions. The offshore boundary location at the $59^{\circ} \mathrm{E}$ longitude of the model domain was forced by tidal elevations. Predicted tidal elevations were linearly interpolated to each grid at the east boundary of the model and applied. The large-scale current patterns observed in this model corresponded well with those from published models (Thoppil and Hogan, 2010; Yao and Johns, 2010; Cavalcante et al., 2016) but showed higher resolution in the nearshore areas, which is important for modeling larval trajectories on the many inshore reefs.

To simulate larval transport and retention, the particle tracking module of MIKE 21 was used (DHI Water and Environment, 2001), simulating transport and fate of suspended particles using a Lagrangian random-walk technique. Larval traits important for dispersal (larval weight, spawn number, and pelagic larval duration) as well as spawning period and spawning date were averaged from literature (Connolly and Baird, 2010). Larval size was taken as $0.04 \mathrm{mg}$, with one modeled particle deemed equivalent to 100 larvae. The simulation period for particle tracking (i.e., pelagic larval dispersal) was taken as 45 days; after this period the majority of coral larvae are considered to have settled or to no longer be competent. Larvae were defined as passive (no swimming), neutrally buoyant, particles that followed the prevailing flow. 24 release sites across eight source areas were modeled (Figure 8). Release was started at peak high tide at full moon on 27 April (8 a.m.) and continued for 8 days, finishing on 4 May 2010 (23.00), as was observed to be peak spawning period in the study area (Bauman et al., 2011; Howells et al., 2014). Release periods occurred twice a day following the 2 high tides, covering 16 tidal cycles, again comparable to field observations. Within each release period 1,000 particles were released from each site, resulting in 1.6 million larvae being released across the time period. Modeling of larval dispersal was then tracked for 45 days, from 4 May to 18 June. Dispersal and settlement across sites was plotted at 10 day time steps, with larvae tracked hourly. The number of larvae settling into each site was assessed at day 1 , day 15 , day 30 , and day 45 . Data were expressed as a connectivity matrix showing the percentage of larval flow among sites.

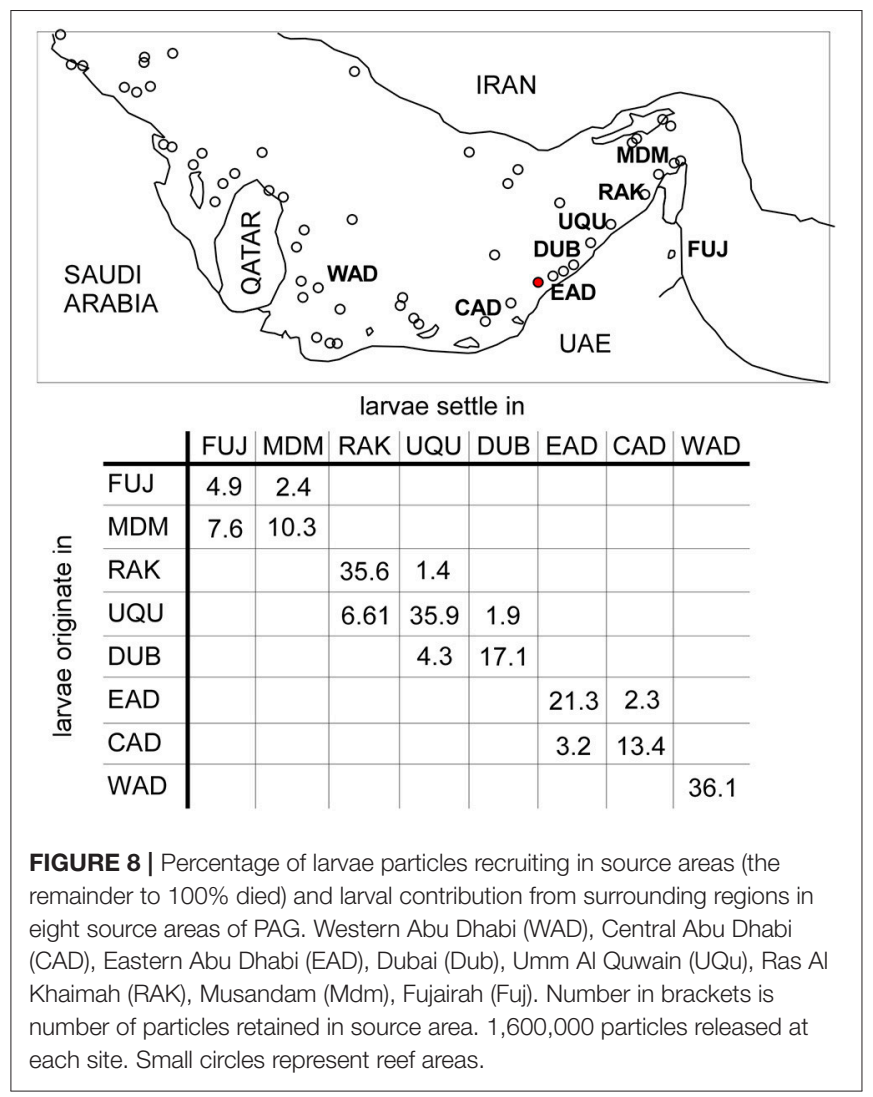

\section{RESULTS}

\section{Environmental and Coral Condition}

Due to the shallow depth $(6 \mathrm{~m})$, water temperatures at Ras Ghanada correlated highly with air temperatures at Sharjah, $96 \mathrm{~km}$ distant (mean daily maxima from 2013 to 2016: Pearson's Product-Moment Correlation 0.88, CI: 0.86-0.89, $t=48.25$, df $=654, p<0.001)$. Therefore, air temperatures could be used as proxy for shallow marine temperature conditions. Since 1944, annual mean daily maxima and annual mean daily averages increased (linear models, Figure 1). PAG bleaching events coincide with high temperatures in August (Riegl and Purkis, 2015) and the mean August maxima increased more than annual means (Figure 2). Mean August maximum air temperatures rose from 1977-2017 (the period with a continuous record) by $2.34^{\circ} \mathrm{C}$. PAG bleaching thresholds were at $35.7^{\circ} \mathrm{C}$ water temperature for 1 day and 3 weeks of daily mean temperatures at $35^{\circ} \mathrm{C}$ (Riegl et al., 2011) suggesting a steady increase of hot days at Sharjah $\left(45^{\circ} \mathrm{C}\right.$ daily max. air temperature correlates with $\sim 35^{\circ} \mathrm{C}$ daily max. water temperature at Ras Ghanada) will increase the likelihood of bleaching and result in a shorter temporal spacing between bleaching events on the Ras Ghanada reef.

Based on temperature and monitoring records, two distinct phases exist in coral population monitoring data. A severely disturbed period (SD) included the triple bleaching and mortality events of 2010/11/12, that were sandwiched between a prior 
(2008-2010) and subsequent (2013-2017) moderately disturbed (MD) period. During the latter only some disease and low-level bleaching (paling) without drastic mortality occurred and not all species were affected. In August 2017, another bleaching event was recorded.

\section{Matrix-Based Derivation of Coral Population Dynamics}

For the five most common species at Ras Ghanada (A. downingi, P. harrisoni, D. pallida, P. lamellina, C. microphthalma) transition matrices for five life-stages during $\mathrm{SD}$ and $\mathrm{MD}$ periods were solved from observed size distributions. These five species showed clear distributional peaks with regards to certain environments, being the characteristic species of stress-specific communities. While they can co-occur, dominance patterns differed among environments (Figure 3).

Correspondingly, parameters of the matrix models, as well as model structure, differed among species and among the two periods with different disturbance frequency (SD, MD; Figure 4).

Impacts of severe disturbances on life-dynamics, when comparing $\mathrm{SD}$ and $\mathrm{MD}$ matrices, were most marked in $A$. downingi and $P$. harrisoni. In both species, growth into the largest SC5 ceased, leading to eventual loss of this size class (no growth into SC5, no loop within, no shrinkage from SC5; Figure 4). In A. downingi, loops (i.e., retention within size-class $=$ absence of growth) became much more important in the SD period and in A. downingi and $P$. harrisoni shrinkage strongly increased. This resulted in SC1 replacing $\mathrm{SC} 2$ as the most common SC at theoretical stableSC distribution in both species (expressed by bubble-sizes in Figure 4). In the other species, no SC were lost, but growth transitions also decreased and shrinkages increased with the effect of stronger contribution to the smaller SC. In D. pallida, population size-distribution was expected to change so that smaller SC (SC3 $\rightarrow \mathrm{SC} 2)$ would predominate at the theoretical stable SC distribution. P. lamellina and C. microphthalma only exhibited some shrinkage with increases in SC1 and 2 with SC3 (P. lamellina) and SC4 (C. microphthalma) remaining predominant.

Matrices from moderately and severely disturbed periods were compared as a Life Table Response Experiment (LTRE, Caswell, 2001). The results highlight the differences between the MD and SD matrices (Figure 5A) and the effects of changes on the dominant eigenvalue (Figure 5B), which is equivalent to the population's asymptotic growth rate. The biggest changes in transition probabilities were in A. downingi and P. harrisoni. The strongest overall changes in any species were the very strong shrinkage of large colonies (SC4) into small fragments (SC1) in $P$. harrisoni. In $D$. pallida and $P$. daedalea, the smallest changes in transition probabilities of all species were observed, with small but equitable contributions to eigenvalue change across the SCs. In C. microphthalma relatively larger changes in transition probabilities were seen, and changes in the growth probabilities of the largest size classes had the strongest influence on the eigenvalue. In all species, except $A$. downingi, changes in survival and shrinkage in SC5 most influenced the eigenvalue. In A. downingi and C. microphthalma, it was changes in SC4.

Transition matrices of all species had been solved without explicit assumption of local recruitment, and dominant eigenvalues were mostly $<1$ (Figure 6A). This suggested shrinking local populations and a need for connectivity to other populations for larvae import (and export). The slight increase in asymptotic growth rate in the SD matrices of four species can be traced to shrinkage. Shrinkage due to partial tissue loss will increase the smallest SC (i.e., the "recruits"), because many small tissue fragments remain after partial colony mortality. This is a form of asexual reproduction that can provide a transient boost to population numbers, but comes at the cost of reduction of the large SC and therefore overall population (sexual) fecundity (Figure 6).

Severe disturbances (SD matrices) resulted in more of the populations being in small SC due to partial or total mortality of colonies, with concomitant loss of large SC and decline of total tissue-covered area. Since population fecundity declines exponentially with coral size, the combination of loss in large corals (demographic change in Figure 6B) and overall tissue covered area (demographic plus cover change in Figure 6B) translated into significant fertility loss (Figure 6B).

\section{Theoretical (Matrix-Based) Connectivity Considerations}

Connectivity requirement to keep the dominant eigenvalue of the metapopulation matrix $>1$ depended heavily on correlation of disturbance across the metapopulation. In the extreme cases where there were either no severe disturbances across the entire metapopulation, or severe disturbances everywhere, the connectivity requirements are shown in Figure 7. P. harrisoni and, to a lesser degree, $D$. pallida and $P$. lamellina had a higher theoretical connectivity requirement in moderately disturbed conditions, because during severe disturbance, the abundant shrinkage into the smallest size-classes boosted asexual recruitment. This suggests that these three species should be resilient to severe disturbances. Both C. microphthalma and A. downingi required more connectivity-derived recruitment in severe disturbances, especially when correlated across the metapopulation (SD upstream, SD downstream), A. downingi requiring a five-fold increase. In C. microphthalma, the lower whole-colony mortality and tissue loss resulted in a lower connectivity requirement when demographic change and cover change were taken into account (Figure 7B).

The key demographic effects that could influence the persistence vs. winnowing of species from the community were:

- Severe reduction of large size classes and total populations size due to whole colony mortality (A. downingi)

- Reduction of large size classes without reduction of population size due to partial mortality ( $P$. harrisoni)

- Reduction of relative cover in community due to loss of colonies and slow regeneration (A. downingi)

- Loss of relative population fertility due to loss of most fertile large size classes (all species, least in C. microphthalma) 
- Severely increased need for connectivity due to loss of local fecundity (A. downingi)

- Steep decline in cover causing lower local fertility and thus also connectivity declines (A. downingi).

\section{Oceanographic Model of Connectivity}

Declining fecundity and increased requirements for connectivity were central issues that could, besides levels of mortality, determine which species would be winnowed from the local fauna. In the oceanographic model, southern PAG showed clear indications of local retention of larvae (Figure 8) where between 5 and $36 \%$ of all larvae were locally retained in their region of origin. Connectivity between sources was apparent between (i) Dubai, Umm al Quwain and Ras al Khaimah, and (ii) central and eastern Abu Dhabi (Figure 8). Connectivity was primarily associated with larvae moving between neighboring subpopulations. Dubai, Umm al Quwain, and Ras al Khaimah sites showed low larval connectivity. From Dubai, $4.6 \%$ of larvae moved to Umm al Quwain, 6.61\% of larvae released there reached Ras al Khaimah sites. Larval connectivity from west to east was lower. $1.37 \%$ of Ras al Khaimah larvae appeared in Umm al Quwain, 1.87\% of Umm al Quwain larvae appeared in Dubai. $3.15 \%$ of larvae from central Abu Dhabi were apparent in eastern Abu Dhabi, while $2.28 \%$ of larvae released in eastern Abu Dhabi moved the opposite way. Western Abu Dhabi seemed isolated from all other sites. There was no larval connection between the adjacent areas of eastern Abu Dhabi and Dubai or Ras Al Khaimah and Hormuz Straits. Most larvae from the Hormuz Straits dispersed into northern Gulf of Oman or Iran.

\section{DISCUSSION}

\section{Environmental and Coral Condition}

The environmental variable immediately responsible for most coral death in the southeastern PAG is the average August daily maximum temperature, which increased over the past half century. The primary environmental disturbance used in this paper to measure species-specific variance in demographic effects was the first-ever recorded triple bleaching event that occurred in PAG during 2010/11/12 (Riegl and Purkis, 2015). Such bleaching disturbances are predicted to be common from about 2050 onward (Donner et al., 2005; vanHooidonk et al., 2013) and in 2016/17, a double bleaching event has compromised reef health on the hitherto relatively unaffected Great Barrier Reef (Hughes et al., 2017a).

The principle of species winnowing by environmental disturbances is compatible with concepts like "winners and losers" in response to bleaching (Loya et al., 2001; vanWoesik et al., 2011). Concomitant changes in community structure are not merely theoretical expectations but have already been observed in PAG and elsewhere (Kayanne et al., 2002; Purkis and Riegl, 2005; McClanahan et al., 2011; Edmunds et al., 2014; Harii et al., 2014; McClanahan, 2014, among many others) and it has been shown that coral recovery is delayed in a warming ocean (Osborne et al., 2017). Our study demonstrates the primary mechanisms causing delayed recovery, namely reduced population fertility due to tissue death resulting in fewer, and smaller coral colonies (Figure 6B). This, in turn, requires more recruitment and more connectivity. The former is difficult to achieve in degraded populations (Figure 7), the latter is limited by oceanography (Figure 8).

The disappearance of three previously common species, through much of their former distribution in southeastern PAG, supports the results of our study. All were highly susceptible to bleaching (Loya et al., 2001; McClanahan et al., 2011; vanWoesik et al., 2012). Stylophora pistillata was zone-forming in Tarut Bay (Coles et al., 1995) and quite common in Abu Dhabi until 2010 (pers.comm.). It has disappeared from most of Saudi Arabia and Abu Dhabi (Coles, pers. comm.), but is present in cooler waters at Iranian islands near Hormuz Straits (Samimi-Namin pers.obs. in Riegl et al., 2012a). Pocillopora damicornis was zone-forming at Jana, Saudi Arabia (Vogt, 1995) and present throughout Abu Dhabi. No records exist from Saudi Arabia since 1998 or Abu Dhabi since 2010 but it also still occurs in Iran (Samimi-Namin pers.obs. in Riegl et al., 2012a). Montipora spp. (M. aequituberculata and M. circumvallata listed by Vogt (1993); $M$. aequituberculata, $M$. informis, and $M$. spongiosa listed by F. Benzoni in Riegl et al., 2012a) were common around Qatar until the 1980s (Emara et al., 1985) but are no longer present (Sheppard et al., 2010). The most recent record of this genus comprises three colonies from Kuwait (F. Benzoni in Riegl et al., 2012a). Elsewhere it is only recorded from Iran near Hormuz Straits (Samimi-Namin et al., 2009; and Samimi-Namin in Riegl et al., 2012a).

\section{Matrix-Based Derivation of Coral Population Dynamics}

While differential resilience to environmental stresses has been documented, exact demographic mechanisms of persistence or extinction are less clear (but see Edmunds and Elahi, 2007; Edmunds, 2010; Roth et al., 2010; Doropoulos et al., 2015). Dynamics of PAG species, with respect to potential winnowing from the community, fell into two categories. Firstly, those that were immediately affected by environmental disturbance in its first year (2010), and suffered either predominantly wholecolony mortality and some partial mortality (A. downingi) or predominantly partial mortality and only little whole-colony mortality ( $P$. harrisoni). In both species, populations consisted of markedly smaller corals after disturbance and had changed survival probabilities (Figure 4). In $A$. downingi, both average coral size as well as population size shrank, in $P$. harrisoni population size increased due to abundant colony fission, but average colony size shrank. These corals are referred-to as the "shrinkers." The second group consisted of those species that were not affected in the first, but only the second and/or third disturbance, and while affected by partial mortality, it was less dramatic than in the "shrinkers." This group consisted of D. pallida, P. daedalea, C. microphthalma (Figure 4) and is referred to as the "persisters." Interestingly, temperate corals seem to show different reactions to heating. Populations of temperate, shallow water azooxanthellate corals skewed increasingly toward the larger sizes with heating (Goffredo et al., 2008) or showed no effects at all (Caroselli et al., 2012). 
Shrinkage by partial mortality is problematic for reef corals, since smaller colonies tend to have a higher mortality rate (Edmunds, 2010). Since fecundity tends to scale with size (Hughes et al., 2000), it necessarily declines in a population of smaller corals. Consequently, significant losses in fecundity were observed (Figure 6). However, while sexual fecundity (fertility) was lost, asexual fecundity increased due to abundant fission into surviving tissue remnants. This survival was most marked in the columnar P. harrisoni. Tips of columns tended to survive as isolated ramets, while the areas between columns frequently died (hence the very strong change in the matrix value signifying transition from SC4 $\rightarrow \mathrm{SC} 1$, Figures 4, 5). In A. downingi, there was no clear pattern where tissues survived preferentially but regeneration of several ramets, originating from a single parent colony, was frequent. Also the "persisters" formed many new ramets from tissue remnants.

The abundant production of ramets consisting of variablysized tissue fragments was important in the modeling of population dynamics. Due to the difficulty of correctly identifying small recruits, the smallest size class (SC1) integrated young-of-the-year as well as smaller ramets. This had the effect of raising the population's apparent rate of increase (dominant eigenvalue of the transition matrix; Caswell, 2001; Figure 6A) after the disturbances. While at first sight counterintuitive, the large number of ramets can indeed increase the numerical frequency of larger colonies as they grow (unless ramets fuse again into bigger colonies), but at the cost of genetic diversity.

Even if population growth rate was boosted temporarily by the ramets, declined fertility of smaller colonies may have the opposite effect in the long term. Smaller colonies tend to be less fertile (sexually), and metapopulations of shrinking corals may find recruit flow among subpopulations increasingly compromised. Primarily asexually reproducing populations would be, at least temporarily, lost to the metapopulation with the consequence of breaking connectivity ratchets and endangering the persistence of downstream populations, if these depended on imported recruitment. The metapopulation model suggested potentially negative effects on $A$. downingi, a species requiring good connectivity. Shrinking (both numerically and in colony size) populations required help from connected populations and the need for connectivity increased with correlation of disturbance across the metapopulation. Graham and vanWoesik (2013) showed that ramets of some corals (in the family Merulinidae, formerly Faviidae, related to the PAG "persisters"), can remain fertile even if shrunk below puberty-size. If that was also the case in PAG corals, a strong regeneration mechanism would exist, even in the "shrinkers" (especially P. harrisoni) since fertility and connectivity might decline less than in model calculations. Also, vanWoesik et al. (2011) found that small $(<5 \mathrm{~cm}$, so SC1) Acropora fared better than many other corals, at least in the short term, and that fragmentation and survival from remnants was a long-term winning strategy. Thus, shrinking may not be all problematic and might include some defense mechanisms. This suggests that hope may exist for the "shrinkers" but most certainly for the "persisters," even if they should experience partial mortality in bad periods.

\section{Connectivity Considerations}

The problems created to PAG corals by declining fecundity would be compounded by a dispersal pattern with strong local retention and connectivity primarily among neighboring sub-populations. Further, if the dominant reproductive mode of the population were to shift, impacts of declining overall fertility could be compounded since brooding corals release fewer larvae into the water column than broadcasting species. In the case of the investigated PAG corals, all were broadcast spawners (Bauman et al., 2011), thus changes in the overall number of larvae available for connectivity here would be a simple function of changes in the fertile coral tissue area. The metapopulation suggests highest connectivity requirement under correlated disturbances, i.e., when neighboring populations are stressed. Tissue mortality in neighboring populations would reduce fertility and thus larvae flow, causing disadvantages especially to populations that are highly self-seeding and the connected downstream populations. The most isolated populations would be winnowed first due to the absence of larval rescue. Highly isolated western Abu Dhabi (Figure 8), with higher temperature extremes than eastern Abu Dhabi (Riegl and Purkis, 2012) is home to dense coral growth devoid of Acropora, Monipora, Stylophora, and Pocillopora (Foster et al., 2012; Bauman et al., 2013)-the most heat-sensitive coral genera showing whole-colony mortality and, as demonstrated for $A$. downingi, a high connectivity requirement. Species winnowing as envisaged in this paper seems to have already occurred in PAG, certainly helped by its apparent reproductive isolation.

The observed and modeled population dynamics of PAG corals suggested a hierarchy of negative demographic effects by environmental stress from the "shrinkers," where A. downingi was worse affected than $P$. harrisoni, to the "persisters." Within the latter, the hierarchy was less clear, but C. microphthalma appeared as a particularly robust species with the least fertility loss and least changes in demographic parameters. Based on the knowledge of environmental disturbances and demographic responses, a generalized scheme of the winnowing response in PAG coral communities was developed (Figure 9). The differentially strong reaction among species to environmental stressors seems to generate disturbance filters related to the thresholds of resistance of individual species. In the discussion regarding changed coral communities in future seas, a better anticipation of which species are likely to get winnowed at specific environmental filters may be a valuable management tool. Many predictions as to impact severity and positioning of potential refuges exist (Riegl and Piller, 2003; vanHooidonk et al., 2013; Cacciapaglia and vanWoesik, 2015) which will be supported and strengthened by an understanding of the demographic realities (such as, shrinking, persisting, and connectivity) that can make or break a refuge.

Since many environmental stressors are ultimately driven by human societal behavior (Hughes et al., 2017b), demonstration of the filters and the reality of species winnowing that cause loss of diversity in reefs can help to predict the evolutionary price tag that will be associated with the absence of effective conservation or climate action or misguided management approaches. PAG 


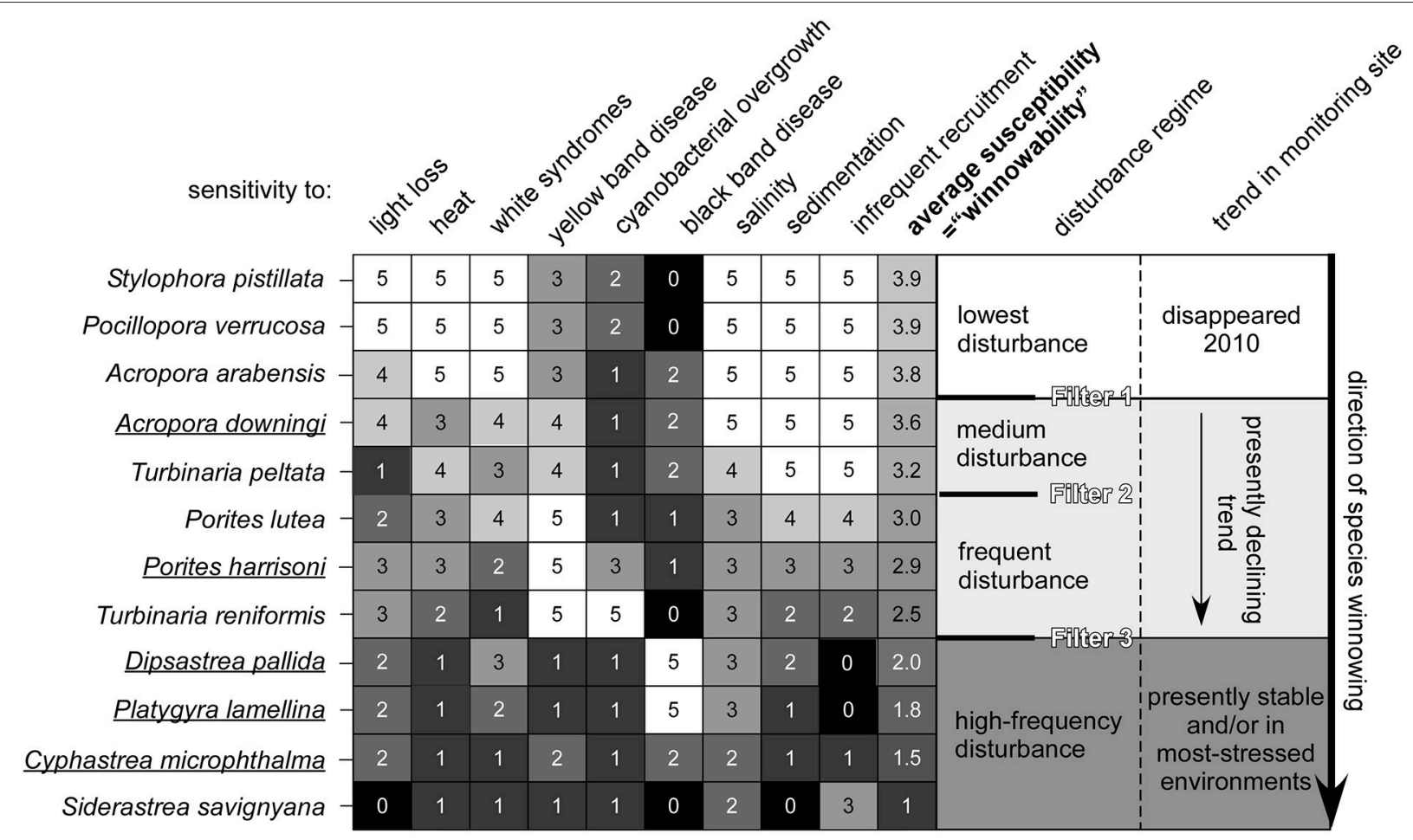

FIGURE 9 | Conceptual environmental filters leading to loss of species from PAG coral communities. Dynamics of underlined species was quantified. Values identify strength of mortality response to environmental parameter $5=$ strongest, 1 = weakest. These values were derived semi-quantitatively from monitoring and impact observations and literature (Sheppard, 1988; Sheppard and Sheppard, 1993; Riegl, 1999; Foster et al., 2012; Bauman et al., 2013; Riegl and Purkis, 2015).

has witnessed severe loss of coral reefs (Sheppard et al., 2010; Sale et al., 2011). Only swift and decisive management action utilizing information as presented within this paper can help to stabilize the continuously declining quality of the region's coral reefs-its most biodiverse but most imperiled ecosystem.

\section{REFERENCES}

Aramco (2007). Arabian Gulf Coral Reef Monitoring. Draft Final report Saudi Aramco/KFUPM/RI Sustaining Research Project. Marine Environmental Sudies - Phase IV. Available online at: https://www.yumpu.com/en/document/view/ 40211588/coral-reef-final-report-2007-Saudi-Aramco

Atweberhan, M., Feary, D. A., Keshavmurthy, S., Chen, A., Schleyer, M., and Sheppard, C. R. C. (2013). Climate change impacts on coral reefs: synergies with local effects, possibilities for acclimation, and management implications. Mar. Pollut. Bull. 74, 526-539. doi: 10.1016/j.marpolbul.2013. 06.011

Bauman, A. G., Baird, A. H., and Cavalcante, G. H. (2011). Coral reproduction in the world's warmest reefs: southern Persian Gulf (Dubai, United Arab Emirates). Coral Reefs 30, 405-430. doi: 10.1007/s00338-010-0711-5

Bauman, A. G., Baird, A. H., Burt, J. A., Pratchett, M. S., and Feary, D. A. (2014). Patterns of coral settlement in an extreme environment: the southern Persian Gulf (Dubai, United Arab Emirates). Mar. Ecol. Prog. Ser. 499, 115-126. doi: 10.3354/meps10662

Bauman, A. G., Pratchett, M. S., Baird, A. H., and Riegl, B. (2013). Variation in the size structure of corals is related to environmental extremes in the Persian Gulf. Mar. Environ. Res. 84, 43-50. doi: 10.1016/j.marenvres.2012.11.007

\section{AUTHOR CONTRIBUTIONS}

$\mathrm{BR}$ conceptualized the paper and wrote matrix models, GC wrote oceanographic model, $\mathrm{SP}$ and $\mathrm{AB}$ collected coral data, $\mathrm{AB}, \mathrm{DF}$, and SS did meta-analyses. All authors wrote and corrected the manuscript.

Bento, R., Hoey, A. S., Bauman, A. G., Feary, D. A., and Burt, J. A. (2016). The implications of recurrent disturbances within the world's hottest coral reef. Mar. Pollut. Bull. 105, 466-472. doi: 10.1016/j.marpolbul.2015.10.006

Budd, A. F., and Pandolfi, J. M. (2010). Evolutionary novelty is concentrated at the edge of coral species distribution. Science 328, 1558. doi: 10.1126/science.1188947

Burt, J. A., Al-Harthi, S., and Al-Cibahy, A. (2011). Long-term impacts of coral bleaching events on the world's warmest reefs. Mar. Environ. Res. 72, 225-229. doi: 10.1016/j.marenvres.2011.08.005

Burt, J. A., Al-Khalifa, K., Khalaf, E., AlShuwaikh, B., and Abdulwahab, A. (2013). The continuing decline of coral reefs in Bahrain. Mar. Pollut. Bull. 72, 357-363. doi: 10.1016/j.marpolbul.2012.08.022

Burt, J. A., Bartholomew, A., and Usseglio, P. (2008). Recovery of corals a decade after a bleaching event in Dubai, United Arab Emirates. Mar. Biol. 154, 27-36. doi: 10.1007/s00227-007-0892-9

Cacciapaglia, C., and vanWoesik, R. (2015). Reef-coral refugia in a rapidly changing ocean. Global Change Biol. 21, 2272-2282. doi: 10.1111/gcb.12851

Caroselli, E., Zaccanti, F., Mattioli, G., Felini, G., Levy, O., Dubinsky, Z., et al. (2012). Growth and demography of the solitary scleractinian coral Leptopsammia pruvoti along a sea surface temperature gradient in the Mediterranean Sea. PLoS ONE 7:e37848. doi: 10.1371/journal.pone.0037848 
Caswell, H. (2001). Matrix Population Models. Sunderland: Sinauer, 1-722.

Cavalcante, G. H., Feary, D. A., and Burt, J. A. (2016). The influence of extreme winds on coastal oceanography and its implications for coral population connectivity in the southern Arabian Gulf. Mar. Pollut. Bull. 105, 489-497. doi: 10.1016/j.marpolbul.2015.10.031

Coles, Y. H., Allen, K. W., and Estudillo, R. A. (1995). Mortality of shallow reef corals in the western Arabian Gulf following aerial exposure in winter. Coral Reefs 14, 99-107. doi: 10.1007/BF00303430

Colwell, R. K., Rahbek, C., and Gotelli, N. J. (2004). The Mid-domain effect and species richness patterns: what have we learned so far? Am. Nat. 163, E1-E23. doi: $10.1086 / 382056$

Connolly, S. R. (2005). Process-based models of species distributions and the mid-domain effect. Am. Nat. 166, 1-11. doi: 10.1086/430638

Connolly, S. R., and Baird, A. H. (2010). Estimating dispersal potential for marine larvae: dynamic models applied to scleractinian corals. Ecology 91, 3572-3583. doi: 10.1890/10-0143.1

Coudray, J., and Montaggioni, L. (1982). Coreaux et recifs coralliens de la province Ind-Pacifique: repartition geographique et altitudinale en relation avec la tectonique globale. Bull. Soc. Geol. France 24, 981-983. doi: 10.2113/gssgfbull.S7-XXIV.5-6.981

Cox, B. A. (2003). A review of currently available in-stream water-quality models and their applicability for simulating dissolved oxygen in lowland rivers. Sci. Tot. Environ. 314, 335-377. doi: 10.1016/S0048-9697(03)00063-9

Currie, D. J., and Kerr, J. T. (2008). Test of the Mid-Domain hypothesis: a review of the evidence. Ecol. Monogr. 78, 3-18. doi: 10.1890/06-1302.1

DHI Water and Environment. (2001). MIKE 21- Coastal Hydraulic and Oceanography.

Donner, S. D., Skirving, W. J., Little, C. M., Oppenheimer, M., and HoeghGuldberg, O. (2005). Global assessment of coral bleaching and required rates of adaptation under climate change. Global Change Biol. 11, 2251-2265. doi: 10.1111/j.1365-2486.2005.01073.x

Doropoulos, C., Ward, S., Roff, G., Gonzalez-Rivero, M., and Mumby, P. J. (2015). Linking demographic processes of juvenile corals to benthic recovery trajectories in two common reef habitats. PLOS ONE 10:e128535. doi: 10.1371/journal.pone.0128535

Edmunds, P. J. (2010). Population biology of Porites astreoides and Diploria strigosa on a shallow Caribbean reef. Mar. Ecol. Prog. Ser. 418, 87-104 doi: $10.3354 /$ meps08823

Edmunds, P. J., Adjeroud, M., Baskett, M. L., Baums, I. B., Budd, A. F., Carpenter, R. C., et al. (2014). Persistence and change in community composition of reef corals through present, past and future climates. PLOS ONE 9:e107525. doi: 10.1371/journal.pone.0107525

Edmunds, P. J., and Elahi, R. (2007). The demographics of a 15-year decline in cover of the Caribbean reef coral Montastrea annularis. Ecol. Monogr. 77, 3-18. doi: 10.1890/05-1081

Emara, H. I., El-Samra, M. I., El-Debb, K. Z., and Ahmed, I. F. (1985). “A preliminary study of the chemical characteristics of the coral reef areas in the Qatari waters (Gulf area)," in Proceedings of 5th International Coral Reef Symposium Congress, Vol. 6 (Tahiti), 13-16.

Fatemi, S. M., and Shokri, M. R. (2001). Iranian Coral Reefs Status with Particular Reference to Kish Island, Persian Gulf. Report, Int. Coral Reef Init, IORW. Available online at: http://www.artificialreef.com/reefball.org/album/ iran/iranian_coral_reefs.pdf

Figueiredo, J., Baird, A. H., Harii, S., and Connolly, S. R. (2014). Increased local retention of reef coral larvae as a result of ocean warming. Nat. Clim. Change 4, 498-502. doi: 10.1038/nclimate2210

Foster, K. A., Foster, G., Al-Cibahy, A., Al-Harthi, S., Purkis, S., and Riegl, B. (2012). "Environmental setting and temporal trends in southeastern Gulf communities," in Coral Reefs of the Gulf. Adaptation to Climatic Extremes, eds B. Riegl and S. Purkis (Dordrecht: Springer), 51-70.

Glynn, P. W. (1997). "Eastern Pacific coral reef biogeography and faunal flux: Durham's dilemma revisited," in Proc. 8th International Coral Reef Symposium (Panama), 371-378.

Goffredo, S., Caroselli, E., Mattioli, G., Pignotti, E., and Zaccanti, F. (2008). Relationships between growth, population structure and sea surface temperature in the temperate solitary coral Balanophyllia europea (Scleractinia, Dendrophylliidae). Coral Reefs 27, 623-632. doi: 10.1007/s00338-008-0362-y
Graham, J. E., and vanWoesik, R. (2013). The effects of partial mortality on the fecundity of three common Caribbean corals. Mar. Biol. 160, 2561-2565. doi: 10.1007/s00227-013-2248-y

Grizzle, R. E., Ward, K. M., AlShihi, R. M. S., and Burt, J. A. (2016). Current status of coral reefs in the United Arab Emirates: distribution, extent, and community structure with implications for management. Mar. Pollut. Bull. 105, 515-523. doi: 10.1016/j.marpolbul.2015.10.005

Harii, S., Hongo, C., Ishihara, M., Ide, Y., and Kayanne, H. (2014). Impacts of multiple disturbances on coral communities at Ishigaki Island, Okinawa, Japan, during a 15 year survey. Mar. Ecol. Progr. Ser. 509, 171-180. doi: $10.3354 /$ meps 10890

Hawkins, B. A., Diniz-Filho, J. A. F., and Weis, A. E. (2005). The Mid-domain effect and diversity gradients: is there anything to learn? Am. Nat. 166, E140-E143. doi: $10.1086 / 491686$

Hoegh-Guldberg, O., Cai, R., Poloczanska, E. S., Brewer, P. G., Sundby, S., Hilmi, K., et al. (2014). "The ocean," in Climate Change 2014: Impacts, Adaptation, and Vulnerability. Part B: Regional Aspects Contribution of Working Group II to the Fifth Assessment Report of the Intergovernmental Panel on Climate Change, eds V. R. Barros, C. B. Field, D. J. Dokken, M. D. Mastrandrea, K. J.Mach, et al. (Cambridge, UK: Cambridge University Press), 1655-1731.

Howells, E., Abrego, D., Vaughan, G., and Burt, J. (2014). Coral spawning in the Gulf of Oman and relationship to latitudinal variation in spawning season in the northwest Indian Ocean. Sci. Rep. 4:7484. doi: 10.1038/srep07484

Howells, E. J., Ketchum, R. N., Bauman, A. G., Mustafa, Y., Watkins, K. D., and Burt, J. A. (2016). Species-specific trends in the reproductive output of corals across environmental gradients and bleaching histories. Mar. Pollut. Bull. 105, 532-539. doi: 10.1016/j.marpolbul.2015.11.034

Hughes, T. P., Baird, A. H., Dinsdale, E. A., Moltschawinsky, N. A., Pratchett, M. S., Tanner, J. E., et al. (2000). Supply-side ecology works both ways: the link between benthic adults, fecundity, and larval recruits. Ecology 81, 2241-2249. doi: 10.1890/0012-9658(2000)081[2241:SSEWBW]2.0.CO;2

Hughes, T. P., Barnes, M. L., Bellwood, D. R., Cinner, J. E., Cummings, G. S., Jackson, J. B. C., et al. (2017a). Coral reefs in the Anthropocene. Nature 344, 82-90. doi: 10.1038/nature22901

Hughes, T. P., Kerry, J. T., Alvarez-Noriega, M., Alvarez-Romano, J. G., Anderson, K. D., Baird, A. H., et al. (2017b). Global warming and recurrent mass bleaching of corals. Nature 543, 373-377. doi: 10.1038/nature21707

Jaap, W. C., Szmant, A., Jaap, K., Dupont, J., Clarke, R., Somerfield, P., et al. (2008). "A perspective on the biology of Florida Keys coral reefs," in Coral Reefs of the USA, eds B. M. Riegl, and R. E. Dodge (Dordrecht: Springer), 75-125.

Jackson, J. B. C. (2001). "Ecological extinction and evolution in the brave new ocean" in The Light of Evolution, Biodiversity and Extinction, Vol. 2, eds J. C. Avise, S. P. Hubbell, and F. J. Ayala (Washington, DC: National Academic Press), 5-27.

Jokiel, P., and Martinelli, F. J. (1992). The vortex model of coral biogeography. J. Biogeogr. 19, 449-458. doi: 10.2307/2845572

Jones, A. M., Berkelmans, R., vanOppen, M. J. H., Mieog, J. C., and Sinclair, W. (2008). A community change in the algal endosymbionts of a scleractinian coral following a natural bleaching event: field evidence of acclimatization. Proc. $R$. Soc. B 275, 1359-1365. doi: 10.1098/rspb.2008.0069

Kankara, R. S., Subramanian, B. R., and Sampath, V. (2007). Validation of a deterministic hydrodynamic model in the ICZM framework for Gulf of Kachchh, India. J. Coast. Res. 23, 1324-1331. doi: 10.2112/04-0367.1

Kavousi, J., Seyfabadi, J., Rezai, H., and Fenner, D. (2011). Coral reefs and communities of Qeshm Island, the Persian Gulf. Zool. Stud. 50, 276-283.

Kayanne, H., Harii, S., Ide, Y., and Akimoto, F. (2002). Recovery of coral populations ofter the 1998 bleaching on Shiraho reef, in the southern Ryukyus, NW Pacific. Mar. Ecol. Prog. Ser. 239, 93-103. doi: 10.3354/meps 239093

Kongjandtre, N., Ridgway, T., Ward, S., and Hoegh-Guldberg, O. (2010). Broadcast spawning patterns of Favia species on the inshore reefs of Thailand. Coral Reefs 29, 227-234. doi: 10.1007/s00338-009-0551-3

Loya, Y., Sakai, K., Yamazato, K., Nakano, Y., Sambali, H., and vanWoesik, R. (2001). Coral bleaching: the winners and the losers. Ecol. Lett. 4, 122-131. doi: 10.1046/j.1461-0248.2001.00203.x

Makino, A., Yamano, H., Beger, M., Klein, C. J., Yara, Y., and Possingham, H. P. (2014). Spatio-temporal marine conservation planning to support high-latitude 
coral range expansion under climate change. Divers. Distrib. 20, 859-871. doi: $10.1111 /$ ddi.12184

McClanahan, T. R. (2014). Decadal coral community reassembly on an African fringing reef. Coral Reefs 33, 939-950. doi: 10.1007/s00338-014-1178-6

McClanahan, T. R., Maina, J. M., and Muthiga, N. A. (2011). Associations between climate stress and coral reef diversity in the western Indian Ocean. Global Change Biol. 17, 2023-2032. doi: 10.1111/j.1365-2486.2011. 02395.x

Mohammadizadeh, M., Tavakoli-Kolour, P., and Rezai, H. (2013). Coral reefs and community around Larak island (Persian Gulf). Caspian J. Appl. Sci. Res. 2, 52-60.

Osborne, K., Thompson, A. A., Cheal, A. J., Emslie, M. J., Johns, K. A., Jonker, M. J., et al. (2017). Delayed coral recovery in a warming ocean. Global Change Biol. 23, 3869-3881. doi: 10.1111/gcb.13707

Palumbi, S. R., Barshis, D. J., Traylor-Knowles, N., and Bay, R. A. (2014). Mechanisms of reef coral resistance to future climate change. Science 344, 895-898. doi: 10.1126/science. 1251336

Pratchett, M. S., Baird, A. H., Bauman, A. G., and Burt, J. A. (2017). Abundance and composition of juvenile corals reveals divergent trajectories for coral assemblages across the United Arab Emirates. Mar. Pollut. Bull. 114, 1031-1035. doi: 10.1016/j.marpolbul.2016.11.036

Precht, W. F., and Aronson, R. B. (2004). Climate flickers and range shifts of reef corals. Front. Ecol. Env. 2, 307-314. doi: 10.1890/15409295(2004)002[0307:CFARSO]2.0.CO;2

Purkis, S. J., Renegar, D. A., and Riegl, B. M. (2011). The most temperatureadapted corals have an Achilles' Heel. Mar. Pollut. Bull. 62, 246-250. doi: 10.1016/marpolbul.2010.11.005

Purkis, S. J., and Riegl, B. (2005). Spatial and temporal dynamics of Arabian Gulf coral assemblages quantified from remote-sensing and in situ monitoring data (Jebel Ali, Dubai, U.A.E.). Mar. Ecol. Progr. Ser. 287, 99-113. Available online at: www.jstor.org/stable/24869016

Purser, B. H. (1973). "Sedimentation around bathymetric highs in the southeastern Persian Gulf” in The Persian Gulf, ed B. H. Purser (Berlin; Heidelberg: Springer), 157-179.

Reaka, M. L., Rodgers, P. J., and Kudle, A. U. (2001). "Patterns of biodiversity and endemism in Indo-West Pacific coral reefs," in In the Light of Evolution, Biodiversity and Extinction, Vol. 2. eds J. C. Avise, S. P. Hubbell, and F. J. Ayala (Washington, DC: National Academic Press), 45-63.

Rezai, H., Samimi, K., Kabiri, K., Ehsan, K., Jalili, M., and Mokhtari, M. (2010). Distribution and abundance of the corals around Hengam and Farurgan Islands, the Persian Gulf. J. Persian Gulf 1, 7-15.

Rezai, H., Wilson, S., Claereboudt, M., and Riegl, B. (2004). "Coral reef status in the ROPME sea area: Arabian/Persian Gulf, Gulf of Oman and Arabian Sea" in Status of Coral Reefs of the World: 2004, ed C. Wilkinson (Townsville, QLD: Austr. Inst. Mar. Sci.), 155-169.

Riegl, B. (1999). Coral communities in a non-reef setting in the southern Arabian Gulf (Dubai, UAE): fauna and community structure in response to recurrent mass mortality. Coral Reefs 18, 63-73. doi: 10.1007/s003380050

Riegl, B. M., Benzoni, F., Samimi-Namin, K., and Sheppard, C. (2012a). "The hermatypic scleractinian (hard) coral fauna of the Gulf," in Coral Reefs of the Gulf: Adaptation to Climatic Extremes, eds B. M. Riegl and S. J. Purkis (Dordrecht: Springer), 187-224.

Riegl, B., and Piller, W. E. (2003). Possible refugia for reefs in time of environmental stress. Int. J. Earth Sci. 92, 520-531. doi: 10.1007/s00531-003-0328-9

Riegl, B., and Purkis, S. J. (2009). Model of coral population response to accelerated bleaching and mass mortality in a changing climate. Ecol. Modell. 220, 192-208. doi: 10.1016/j.ecolmodel.2008.09.022

Riegl, B. M., Purkis, S. J., Al-Cibahy, A. S., Abdel-Moati, M. A., and Hoegh-Guldberg, O. (2011). Present limits to heat-adaptability in corals and population-level responses to climate extremes. PLOS ONE 6:e24802. doi: 10.1371/journal.pone.0024802

Riegl, B. M., Sheppard, C. R. C., and Purkis, S. J. (2012b). Human impact on atolls leads to coral loss and community homogenization: a modeling study. PLoS ONE 7:e36921. doi: 10.1371/journal.pone.0036921

Riegl, B., and Purkis, S. J. (2012). Coral Reefs of the Gulf: Adaptation to Environmental Extremes. Dordrecht: Springer. 378.
Riegl, B., and Purkis, S. J. (2015). Coral population dynamics across consecutive mass mortality events. Global Change Biol. 21, 3995-4005. doi: $10.1111 /$ gcb.13014

Riegl, B., Glynn, P. W., Wieters, E., Purkis, S., d'Angelo, C., and Wiedenmann, J. (2015). Water column productivity and temperature predict coral reef regeneration across the Indo-Pacific. Sci. Rep. 5:8273. doi: 10.1038/srep 08273

Rosen, B. R. (1971). The distribution of reef coral genera in the Indian Ocean. Symp. Zool. Soc. Lond. 28, 263-299.

Roth, L., Koksal, S., and vanWoesik, R. (2010). Effects of thermal stress on key processes driving coral-population dynamics. Mar. Ecol. Prog. Ser. 411, 73-87. doi: 10.3354/meps08640

Sale, P. F., Feary, D. A., Burt, J. A., Bauman, A. G., Cavalcante, G. H., Drouillard, K. G., et al. (2011). The growing need for sustainable ecological management of marine communities of the Persian Gulf. Ambio 40, 4-17. doi: 10.1007/s13280-010-0092-6

Samimi-Namin, K., Rezai, H., Kabiri, K., and Zohari, Z. (2009). Unique coral community in the Persian Gulf. Coral Reefs 28:27. doi: 10.1007/s00338-008-0442-z

Schluter, D., and Pennell, M. W. (2017). Speciation gradients and the distribution of diversity. Nature 546, 48-55. doi: 10.1038/nature22897

Sheppard, C. R. C. (1988). "Similar trend, different causes: responses of corals to stressed environments in Arabian seas," in Proceedings of 6th International Coral Reef Congress. Vol. 3, (Townsville, QLD), 297-302.

Sheppard, C. R. C. (2003). Predicted recurrence of mass coral mortality in the Indian Ocean. Nature 425, 294-297. doi: 10.1038/nature 01987

Sheppard, C. R. C., Al-Hoseine, M., Al-Jamali, F., Al-Yamani, F., Baldwin, R., Bishop, J., et al. (2010). The Persian/Arabian Gulf: a young sea in decline. Mar. Pollut. Bull. 60, 13-38. doi: 10.1016/j.marpolbul.2009. 10.017

Sheppard, C. R. C., and Sheppard, A. L. S. (1993). Corals and coral communities of Arabia. Fauna Saudi Arabia 12, 3-170.

Shlesinger, Y., Goulet, T. L., and Loya, Y. (1998). Reproductive patterns of scleractinian corals in the northern Red Sea. Mar. Biol. 132, 691-701. doi: $10.1007 / \mathrm{s} 002270050433$

Shuail, D., Wiedenmann, J., D’Angelo, C., Baird, A. H., Pratchett, M. S., Riegl, B., et al. (2016). Local bleaching thresholds established by remote sensing techniques vary among reefs with deviating bleaching patterns during the 2012 event in the Arabian/Persian Gulf. Mar. Pollut. Bull. 105, 654-659. doi: 10.1016/marpolbul.2016.03.001.

Soong, K. (1993). Colony size as a species character in massive corals. Coral Reefs 12, 77-83. doi: 10.1007/BF00302106

Thoppil, P. G., and Hogan, P. J. (2010). A modeling study of circulation and eddies in the Persian Gulf. J. Phys. Oceanogr. 40, 2122-2143. doi: 10.1175/2010JPO4227.1

vanHooidonk, R., Maynard, J. A., and Planes, S. (2013). Temporary refugia for coral reefs in a warming world. Nat. Clim. Change 3, 508-511. doi: $10.1038 /$ nclimate 1829

vanWoesik, R., Franklin, E. C., O’Leary, J. O., McClanahan, T. R., Klaus, J. S., and Budd, A. F. (2012). Hosts of Plio-Pleistocene past reflect modern-day coral vulnerability. Proc. R. Soc. B. doi: 10.1098/rspb.2011.2621

vanWoesik, R., Sakai, K., Ganase, K., and Loya, Y. (2011). Revisting the winners and the losers a decade after coral bleaching. Mar. Ecol. Prog. Ser. 434, 67-76. doi: 10.3354/meps09203

Veron, J. E. N. (1995). Corals in Space and Time. Sydney: University of NSW Press. 321.

Veron, J. E. N., deVantier, L. M., Turak, E., Green, A. L., Kinninmonth, S., StaffordSmith, M., et al. (2009). Delineating the coral triangle. Galaxea 11, 91-100. doi: $10.3755 /$ galaxea.11.91

Vogt, H. P. (1993). "Investigations on coral reefs in the Jubail Marine Wildlife sanctuary using underwater video recordings and digital image analysis," in A Marine Wildlife Sanctuary for the Arabian Gulf. Environmental Research and Conservation Following the 1991 Gulf War Oil Spill, eds F. Krupp, A. H. Abuzinada, and I. A. Nader (Riyadh; Franfrt: Senckenberg Research Institute), 302-336. 
Vogt, H. P. (1995). Coral reefs in Saudi Arabia: 3.5 years after the Gulf War oil spill. Coral Reefs 14, 271-273. doi: 10.1007/BF00334351

Yamano, H., Sugihara, K., and Nomura, K. (2011). Rapid poleward range extension of tropical reef corals in response to rising sea surface temperatures. Geophys. Res. Lett. 38:L04601. doi: 10.1029/2010GL046474

Yao, F., and Johns, W. E. (2010). A HYCOM modeling study of the Persian Gulf. 1. Model configuration and surface circulation. J. Geophys. Res. 115:C11017. doi: 10.1029/2009JC005781

Zhao, M., Riegl, B., Yu, K., Shi, Q., Zhang, Q., Liu, G., et al. (2016). Model suggests potential for Porites coral population recovery after removal of anthropogenic disturbance (Luhuitou, Hainan, South China Sea). Sci. Rep. 6:33324. doi: 10.1038/srep33324

Zhao, Y. W., Xu, M. J., Xu, F., Wu, S. R., and Yin, X. (2014). Development of a zoning-based environmental-ecological coupled model for lakes: a case study of Baiyangdian Lake in northern China. Hydrol. Earth Syst. Sci. 18, 2113-2126. doi: 10.5194/hess-18-2113-2014

Conflict of Interest Statement: The authors declare that the research was conducted in the absence of any commercial or financial relationships that could be construed as a potential conflict of interest.

Copyright (C) 2017 Riegl, Cavalcante, Bauman, Feary, Steiner and Purkis. This is an open-access article distributed under the terms of the Creative Commons Attribution License (CC BY). The use, distribution or reproduction in other forums is permitted, provided the original author(s) or licensor are credited and that the original publication in this journal is cited, in accordance with accepted academic practice. No use, distribution or reproduction is permitted which does not comply with these terms. 